\title{
Making Employee Health Benefits Understandable: The Summary- Plan-Description Failure and How to Fix It
}

Christopher Switzer

Follow this and additional works at: https://scholarlycommons.law.case.edu/caselrev

Part of the Law Commons

\section{Recommended Citation}

Christopher Switzer, Making Employee Health Benefits Understandable: The Summary-Plan-Description Failure and How to Fix It, 72 Case W. Rsrv. L. Rev. 175 (2021)

Available at: https://scholarlycommons.law.case.edu/caselrev/vol72/iss1/8

This Note is brought to you for free and open access by the Student Journals at Case Western Reserve University School of Law Scholarly Commons. It has been accepted for inclusion in Case Western Reserve Law Review by an authorized administrator of Case Western Reserve University School of Law Scholarly Commons. 


\section{Making Employee Health BENEFITS UNDERSTANDABLE: The Summary-Plan-Description FAILURE AND HOW TO FIX IT}

\section{Contents}

INTRODUCTION 175

I. ERISA and Employer-Sponsored Health Plans ..................... 181

A. ERISA's Purpose: To Protect Health-Plan Participants?................. 182

B. SPD Background and Requirements .................................... 185

II. Employee HeAlth Literacy in CRisis ................................. 189

A. Employee Health Literacy .....................................................190

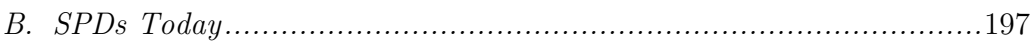

III. SPDs IN CourT..................................................... 201

A. "[C]alculated to be understood by the average plan participant"? ......202

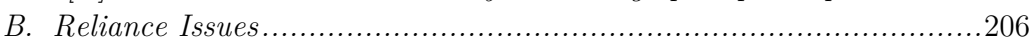

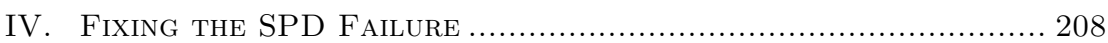

A. Working with Current Employer Practices ................................210

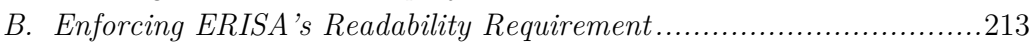

1. Using Literacy Tools to Draft Tailored SPDs .............................. 213

2. Identifying the Average Plan Participant ................................. 216

3. Interpreting SPDs in Court.................................................. 218

C. Helping Participants Rely on Employer Communications ................219

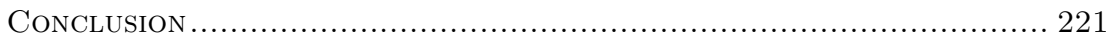

\section{INTRODUCTION}

Poor health literacy costs Americans between $\$ 106$ billion and $\$ 238$ billion each year. ${ }^{1}$ Those numbers represent between $7 \%$ and $17 \%$ of

1. John A. Vernon, Antonio Trujillo, Sara Rosenbaum \& Barbara DeBuono, Low Health Literacy: Implications for National Health Policy 1 (2007), https://publichealth.gwu.edu/departments/ healthpolicy/CHPR/downloads/LowHealthLiteracyReport10_4_07.pdf [https://perma.cc/QWP5-TKDL].

Prior to the Biden administration, the National Library of Medicine's website displayed the information in the Low Health Literacy report on its health-literacy page. Health Literacy, NAT'L LIBR. OF MED. (citing VERNON ET AL., supra), https://perma.cc/BK9P-4MZN (last visited Oct. $2,2020)$. The updated website discusses the impact of health literacy on 
personal health care expenditures. ${ }^{2}$ Health literacy includes the ability to read medical terminology and understand treatment but, key to this Note, health literacy also includes the ability to read and analyze health-plan communications. ${ }^{3}$

In 2019, almost half of Americans received health insurance through an employer. ${ }^{4}$ In theory, employees learn about their benefits through a benefits summary called a summary plan description - an SPD. ${ }^{5}$ So, with SPD in hand, do average Americans with employer-sponsored health insurance understand their medical benefits? Unsurprisingly, probably not. According to UnitedHealthcare, one of America's largest health insurers, ${ }^{6}$ less than $10 \%$ of its survey respondents understood all of these basic health-insurance terms: premium, deductible, out-ofpocket maximum, and coinsurance. ${ }^{7}$ And even though a national

individuals but is now silent on the societal costs of low health literacy. An Introduction to Health Literacy, NAT'L LIBR. OF MED., https://nnlm.gov/ guides/intro-health-literacy [https://perma.cc/UAH7-CFRA] (Sept. 10, 2021, 10:35).

2. VERNON ET AL., supra note 1, at 1 (also noting that that amount could cover the 47 million uninsured Americans in 2006).

3. Mark Kutner, Elizabeth Greenberg, Ying Jin \& Christine Paulsen, U.S. Dep't of Educ., The Health Literacy of America's Adults: Results from the 2003 National Assessment of Adult LiTERACY 6 (2006), https://nces.ed.gov/pubs2006/2006483.pdf [https:// perma.cc/Q6CR-4B6N]. For other definitions of health literacy, see the Patient Protection and Affordable Care Act [ACA], Pub. L. No. 111-148, $\S 5002(21), 124$ Stat. 119, 591 (2010) (codified as amended at 42 U.S.C. $\S 295 \mathrm{p}(21))$; Healthy People 2030, Health Literacy in Healthy People, U.S. DeP'T of Health AND Hum. Servs., https://health.gov/our-work/ healthy-people-2030/about-healthy-people-2030/health-literacy-healthypeople [https://perma.cc/55D9-592U] (last visited Oct. 2, 2020).

4. Health Insurance Coverage of the Total Population, KAISER FAM. Found., https://www.kff.org/other/state-indicator/total-population/? currentTimeframe $=0 \&$ sortModel $=\% 7 \mathrm{~B} \% 22$ colId $\% 22: \% 22$ Location $\% 22, \%$ 22sort\%22:\%22asc\%22\%7D [https://perma.cc/4R9R-UWPV] (last visited Nov. 13, 2020).

5. Employee Retirement Income Security Act of 1974 [ERISA] § 102, 29 U.S.C. § 1022.

6. Reed Abelson, Major U.S. Health Insurers Report Big Profits, Benefiting from the Pandemic, N.Y. Times (Aug. 5, 2020), https://www.nytimes.com/ 2020/08/05/health/covid-insurance-profits.html [https://perma.cc/6JWFCWN3].

7. Les Masterson, UnitedHealth Survey: Most Americans Don't Understand Basic Health Plan Terms, Healthcare Dive (Oct. 10, 2017), https://www.healthcaredive.com/news/unitedhealth-survey-most-americansdont-understand-basic-health-plan-term/506895/\#: :text=The\%20United Healthcare\%20Consumer\%20Sentiment\%20Survey,pocket\%20maximum\%20a nd\%20co\%2Dinsurance [https://perma.cc/F7ZN-983Q] (summarizing UnitedHealthcare, Consumer Sentiment Survey: 2017 Executive 
assessment of health literacy found that respondents with employersponsored insurance were more health literate than other insured respondents, the literacy difference was only marginal. ${ }^{8}$ Although one industry survey states that a majority of respondents were confident in analyzing their health insurance, ${ }^{9}$ another shows that $96 \%$ of respondents overestimated their own health-insurance understanding. ${ }^{10}$

Summary 13 (2017), https://newsroom.uhc.com/content/dam/newsroom/ 2017_UHC_Consumer_Sentiment_Survey___Executive_Summary_ 10-05-2017___FINAL_d39i76.pdf [https://perma.cc/SUF5-KQX5]).

8. See KUtNer ET AL., supra note 3, at 17; infra notes 101-03 and accompanying text.

9. Throughout the discussion, this Note will refer to industry studies and surveys. These reports are often compiled by insurance carriers, see, e.g., UNITEDHEALTHCARE, supra note 7 , so they might normally suffer from convenience errors. But for this Note, either each report indicates that it polled a probability or representative sample, or this Note's author specifically points out concerns about the survey population in a footnote. For a discussion of why researchers should survey a representative sample and not a convenience sample, see Louis M. REA \& Richard A. Parker, Designing and Conducting Survey Research: A Comprehensive Guide 198-99 (4th ed. 2014). Unfortunately, the last major national study on health literacy that presented results by insurance type was done by the U.S. Department of Education in 2003. See generally KUTNER ET AL., supra note 3. This landmark study continues to be quoted. See, e.g., Maya T. Miller, Examining Health Literacy in the ACA, The Century Found. (Sep. 8, 2016), https://tcf.org/content/commentary/examining-health-literacy-aca/? session=1 [https://perma.cc/3RYJ-4FSP]; Müberra Devrim Güner \& Perihan Elif Ekmekci, A Survey Study Evaluating and Comparing the Health Literacy Knowledge and Communication Skills Used by Nurses and Physicians, 56 J. of Health Care Org., Provision, and Fin. 2, 9 n.16 (2019), https://www.ncbi.nlm.nih.gov/pmc/articles/PMC6659174/pdf/10. 1177_0046958019865831.pdf [https://perma.cc/LGK9-4WC2]; Baraka Muvuka, Ryan M. Combs, Suur D. Ayangeakaa, Nida M. Ali, Monica L. Wendel \& Trinidad Jackson, Health Literacy in African-American Communities: Barriers and Strategies, 4 Health Literacy Rsch. \& PRAC. e138, e138 (2020), https://www.healio.com/public-health/journals/ hlrp/2020-7-43/\%7B5babe592-c5b9-48fd-97f5-9b70adcb543e\%7D/healthliteracy-in-african-american-communities-barriers-and-strategies.pdf [https://perma.cc/4NW3-FWNL]. But more recent numbers are helpful to frame the discussion, especially since the Department's study came out before the Affordable Care Act. Pub. L. No. 111-148, 124 Stat. 119 (2010).

10. DirectPath, 2020 Consumer Survey Report: The Health Care LITERACY GAP 9 (2020), https://www.directpathhealth.com/report/2020consumer-report-health-care-literacy-gap-personalized-benefits-education-keycost-saving (citing 4 Basic Health Insurance Terms 96\% of Americans Don't Understand, POLICYGEnIUs (Jan. 24, 2018), https://www.policygenius.com/ health-insurance/health-insurance-literacy-survey/\#survey-results [https://perma.cc/5QSH-6B5X])). You can download the DirectPath report here: https://www.directpathhealth.com/report/2020-consumerreport-health-care-literacy-gap-personalized-benefits-education-key-costsaving [https://perma.cc/FL6F-D4GC]. 
The SPD is supposed to work for Americans, even those with low health literacy. In 1974, Congress, motivated by a "lack of employee information and adequate safeguards" in employee-benefit plans, ${ }^{11}$ required that administrators provide an SPD to plan participants. ${ }^{12}$ In contrast to a comprehensive plan document, an SPD is supposed to provide an easy-to-understand summary of the plan's benefits. ${ }^{13}$ Therefore, an SPD "shall be written in a manner calculated to be understood by the average plan participant." 14 Unfortunately, agency regulations do not provide much concrete guidance about how to effect the readability requirement. ${ }^{15}$

For clarity's sake, it is important to define a few terms up front. A plan is a set of terms, written in a plan document, designed to provide benefits to the individuals it covers. ${ }^{16}$ The plan sponsor is the entity that establishes the plan and selects its terms - for instance, the employer. ${ }^{17}$ The plan administrator is the entity or person who handles day-to-day plan obligations such as distributing SPDs ${ }^{18}$ - again, it may be the employer but it could be another entity, such as an insurer or third-party administrator. ${ }^{19}$ Plan participants are employees who enroll

11. ERISA, Pub. L. No. 93-406, § 2, 88 Stat. 829, 832 (1974) (codified as amended at 29 U.S.C. $\S 1001$ ).

12. ERISA $\S 101(\mathrm{a})$ (codified as amended at 29 U.S.C. $\S 1021(\mathrm{a})$ ).

13. Compare 29 U.S.C. $\S 1102(a)(1)$ with 29 U.S.C. $\S 1022(\mathrm{a})$.

14. $\quad$ ERISA $\S 102(a), 29$ U.S.C. $\S 1022(a)$.

15. See 29 C.F.R. § 2520.102-2(a) (2020); see also infra notes 87-89 and accompanying text.

16. See ERISA § 3(1) (defining an "employee welfare benefit plan" as "any plan, fund, or program . . . established . . for the purpose of providing" benefits); ERISA § 402(a)(1) (requiring that plans "shall be established and maintained pursuant to a written instrument").

17. ERISA $\S 3(16)(\mathrm{B})$.

18. Id. $\S 101(\mathrm{a})$. Because the law requires administrators to furnish SPDs that meet ERISA's requirements, $i d$., administrators are, in practice, responsible for drafting SPDs or hiring someone else to draft them.

19. ERISA defines an "administrator" as either "the person specifically so designated by the terms of the [plan document]" or, if the plan document does not designate anyone, the plan sponsor. $I d$. § 3(16)(A). This Note will use administrator and plan administrator interchangeably. Technically, ERISA reserves plan administrator for its Title II, id. $\S 1015(\mathrm{~g})$, which deals with tax concerns related to employee retirement plans. See History of EBSA and ERISA, U.S. DEP'T OF LAB., https://www.dol.gov/agencies/ ebsa/about-ebsa/about-us/history-of-ebsa-and-erisa [https://perma.cc/3MS4M23V] (last visited Feb. 1, 2021). But in practice, plan administrator is also used to refer to the administrator of an employer-provided health plan. See, e.g., Walmart, Inc., 2020 Associate Benefits Book: Summary Plan Descriptions with 2021 Summaries of Material ModificAtions 281 (2020), https://one.walmart.com/content/dam/ 
in benefits. ${ }^{20}$ Beneficiaries are any individuals who are entitled to benefits under a plan, which includes participants and any spouses or dependents whom participants enroll in benefits..$^{21}$ If internalizing these definitions all at once is difficult for you, then you may have a sense of how plan participants feel when they attempt to decipher the benefits described in their SPD.

Courts may need to review SPDs when plan participants sue based on those SPDs. ${ }^{22}$ Courts often apply an objective standard when reading SPDs - for instance, "from the perspective of a layperson." 23 The courts use such standards despite the statutory requirement that plan administrators tailor their SPD to "the average plan participant." 24 As a result, administrators favor comprehensive disclosure and objectively unambiguous language over language tailored to participants' healthliteracy level. ${ }^{25}$ Therefore, they write health-plan SPDs using technical language ${ }^{26}$ and SPDs do not effectively communicate plan benefits to participants. ${ }^{27}$

themepage/pdfs/AssociateBenefitsBook-2021.pdf [https://perma.cc/LQ26QJSL]. Therefore, while administrator is the legally correct term, this Note will use the terms interchangeably as needed for ease of communication.

20. $\quad$ ERISA $\S 3(7)$.

21. Id. $\S 3(8)$.

22. In court, a participant can claim that their plan's SPD creates the plan's terms and the participant is entitled to benefits under those terms, or that the SPD was misleading and the participant was justified in relying on the SPD. See ERISA § 502(a)(1)(B), (a)(3)(B); infra text accompanying notes 149-50, 165-67; infra notes 201-02 and accompanying text.

23. See, e.g., Harris Methodist Fort Worth v. Sales Support Servs. Inc. Emp. Health Care Plan, 426 F.3d 330, 336 (5th Cir. 2005).

24. ERISA § $102(\mathrm{a})$.

25. Advisory Council on Employee Welfare and Pension Benefit Plans, Advisory Council Report of the Working Group on Health and Welfare Benefits Plans' Communications, U.S. DEP'T OF LAB., https://www.dol.gov/ agencies/ebsa/about-ebsa/about-us/erisa-advisory-council/2005-healthand-welfare-benefit-plans-communications [https://perma.cc/7ZPF-85BM] (last visited Jan. 6, 2021) ("When an SPD, which must explain complex plan provisions, is written following ERISA and [Department of Labor] guidelines and drafted to mitigate litigation risk, the resulting communication is often ineffective in explaining the plan to participants."); see Betty Sosnin, What's in Your Summary Plan Description?, SHRM (Aug. 1, 2007), https://www.shrm.org/hr-today/news/hr-magazine/pages/0807sosnin.aspx [https://perma.cc/W7D4-4DV2] ("If a plan denies care for a large dollar amount and a participant sues, the company generally loses if the exclusion or limitation is not clearly stated in the document.").

26. Colleen E. Medill, Richard L. Weiner, Brian H. Bornstein \& E. Kiernan McGorty, How Readable Are Summary Plan Descriptions for Health Care Plans?, 27 Emp. Benefits Rsch. Inst. Notes 1, 1 (2006).

27. Advisory Council, supra note 25. 
But participant-focused communication is in an employer's best interest because comprehensive benefits attract and retain workers, especially when wage increases are unfeasible. ${ }^{28}$ To make up for the SPD's unhelpfulness, employers communicate benefits in other ways, ${ }^{29}$ including websites and annual open-enrollment materials. ${ }^{30}$ But participants cannot always rely on these separate communications in court. $^{31}$ Therefore, if participants rely on the supplemental benefit communications, and those communications contain errors, participants may be left without a remedy. For all the reasons discussed above, the SPD, which Congress intended as an aid for participants, instead becomes a tool that plan sponsors and administrators use to avoid liability.

Part I of this Note explores the SPD's requirements and purpose, including a brief overview of the Employee Retirement Income Security

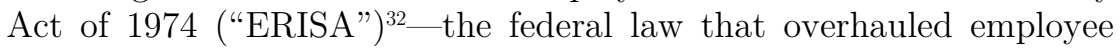
benefits and created the SPD requirement. ${ }^{33}$ This brief background will

28. SHRM, Executive Summary: SHRM Employee Benefits 20193 (2019), available at https://shrm.org/hr-today/trends-and-forecasting/ research-and-surveys/Pages/Benefits19.aspx?_ga=2.117579276.463910689. 1605208001-1584421169.1605208001 [https://perma.cc/6KRD-2XXJ]; accord SHRM, Employee Benefits in 2020: An Executive Summary 4 (2020), https://shrm-res.cloudinary.com/image/upload/v1630503564/2020\% 20Employee\%20Benefits/Benefits_Exec_Summ_FINAL.pdf [https:// perma.cc/5RVF-MCV6] ("Employee benefits will likely play a strongerthan-ever role in attracting talent to organizations, as organizations experience a 2021 'turnover tsunami' . . . .").

29. Advisory Council, supra note 25 ("[A] vast array of communication tools are now used and do a better job than SPDs of explaining the benefits, by using more manageable bites of information delivered at teachable moments.").

30. Id. Employers provide open-enrollment materials because, during annual open enrollment, plan participants need information to help them decide whether to enroll in their employer-sponsored benefits. See When Can I Enroll in My Employer Health Plan?, KAISER FAM. Found., https:// www.kff.org/faqs/faqs-health-insurance-marketplace-and-the-aca/whencan-i-enroll-in-my-employer-health-plan/ [https://perma.cc/8DM3-WU7F] (last visited Apr. 2, 2021) (discussing when participants can normally enroll in benefits). Typically, these annual enrollment choices cannot be changed until the next open-enrollment period unless the participant has a qualifying event - such as a birth or a loss of other coverage - so it is important that employees make informed decisions during open enrollment. $I d$.

31. See Crosby v. Rohm \& Haas Co., 480 F.3d 423, 429 (6th Cir. 2007) (holding that an individualized worksheet could not override plan terms); see also infra notes 200-06 and accompanying text.

32. ERISA, Pub. L. No. 93-406, 88 Stat. 829.

33. ERISA $\S 102,29$ U.S.C. $\S 1022$. For background on the expansive requirements in ERISA, see generally Peter J. Wiedenbeck, FED. Jud. Ctr., ERISA in the Courts (2008). 
introduce SPDs and will also explain why this Note is limited in discussion to health-plan SPDs. Part II analyzes SPDs in the context of national health literacy and explains how SPDs are not meeting their statutory goal of empowering participants. Part III explores how courts apply ERISA's readability requirement and how SPDs are used in litigation to further employer and employee interests.

Lastly, Part IV suggests a three-part solution to the SPD failure: 1) replace the single-document SPD with the tailored communications that plan administrators are already producing; 2) enforce the standard that plan summaries "be written in a manner calculated to be understood by the average plan participant" ${ }^{34}$ and 3) allow participants to sue based on the new summaries. These new tailored summaries would better effect the law's purpose, which is to aid participants in understanding their benefits, and better align with current employer and employee expectations regarding benefits communication.

\section{ERISA and Employer-Sponsored Health Plans}

"[ERISA] is a "comprehensive and reticulated statute." ${ }^{35}$ Passed in 1974, ERISA set a national standard for employee-benefit administration by preempting state laws that interfere with the ERISA regime. $^{36}$ The statute has four "[p]rincipal [p]olicies": to promote informed financial decision making, prevent mismanagement and abuse, protect reliance, and preserve employer autonomy. ${ }^{37}$ Despite ERISA's intricate structure, nothing in ERISA requires health plans to offer particular benefits. ${ }^{38}$ But ERISA does dictate certain benefits requirements for employee retirement plans, such as minimum funding and vesting standards. ${ }^{39}$

A brief look into ERISA's history and purpose will help explain why Congress set more standards for retirement plans than for health plans. This difference will then inform the discussion of the SPD's requirements.

34. ERISA § 102(a) (emphasis added).

35. Firestone Tire \& Rubber Co. v. Bruch, 489 U.S. 101, 108-09 (1989) (quoting Nachman Corp. v. PBGC, 446 U.S. 359, 361 (1980)).

36. ERISA § 514; Aetna Health Inc. v. Davila, 542 U.S. 200, 208 (2004).

37. WiEDENBECK, supra note 33, at 17-24; accord Employee Benefits Security Administration, Fact Sheet: What Is ERISA, U.S. DeP'T OF LAB., https://www.dol.gov/agencies/ebsa/about-ebsa/our-activities/resourcecenter/fact-sheets/what-is-erisa [https://perma.cc/S43H-HH3T] (last visited Nov. 13, 2020).

38. McGann v. H \& H Music Co., 742 F. Supp. 392, 393 (S.D. Tex. 1990), aff'd, 946 F.2d 401 (5th Cir. 1991).

39. WiEDENBECK, supra note 33, at 16. For ERISA's minimum vesting standards, see ERISA $\S 203$. For ERISA's minimum funding standards, see ERISA $\S 302$. 


\section{A. ERISA's Purpose: To Protect Health-Plan Participants?}

The motivation for ERISA's passage explains why the law is focused on retirement-benefit regulation. In 1963, a Studebaker car plant closed, and 6,900 workers either lost their retirement benefits entirely or became entitled to substantially reduced benefits. ${ }^{40}$ At the time, plans had few legal safeguards for participants. Some plans engaged in practices that were legal but arguably unethical - such as terminating an employee just before the employee became entitled to benefits. ${ }^{41}$ Other plans lacked funding or would lose their funding when the plan sponsor was sold or had to pay creditors. ${ }^{42}$ The Studebaker event, combined with other similar events, resulted in a "public outcry" that ultimately motivated Congress to pass ERISA. ${ }^{43}$ President Ford's signing statement ${ }^{44}$ and ERISA itself ${ }^{45}$ also point to protection for retirement benefits as the primary motivator. Current online materials at the Department of Labor ("DOL") emphasize retirement benefits as well. ${ }^{46}$

40. Rebecca J. Miller, Robert A. Lavenberg \& Ian A. Mackay, ERISA: 40 Years Later, J. ACCOUNTANCY (Sept. 1, 2014), https://www.journalofaccountancy. com/issues/2014/sep/erisa-20149881.html [https://perma.cc/2GCY-2MAT] ("Four thousand employees between the ages of 40 and 59 received approximately 15 cents for each dollar of benefit they were owed. . . The remaining 2,900 employees, who all had less than 10 years of service, received nothing."); accord ERISA 40 Timeline Alternate, U.S. DEP'T OF LABOR, https://www.dol.gov/featured/erisa40/timeline/alternative [https://perma.cc/P6Y3-NSL8] (last visited Nov. 13, 2020).

41. Miller et al., supra note 40 , at 88 .

42. Id.

43. Id.; accord Frank Cummings, ERISA After 20 Years: Successes, Failures ES Lessons for the Future of Retirement Income Policy and Health Reform, 22 Tax Mgmt. Comp. Plan. J. 382, 383 (1994) (noting that Congress was motivated "to make sure that people could not work a long time 'under' a pension plan and still get nothing").

44. Statement on the Employee Retirement Income Security Act of 1974, 2 Pub. PAPers 78, 78 (Sept. 2, 1974) ("Under [ERISA], . . . the men and women of our labor force will have much more clearly defined rights to pension funds and greater assurances that retirement dollars will be there when they are needed. Employees will also be given greater tax incentives to provide for their own retirement if a company plan is unavailable.").

45. ERISA, Pub. L. No. 93-406, § 2(a), 88 Stat. 829, 832 (1974) (codified as amended at 29 U.S.C. $\S 1001(\mathrm{a}))$.

46. See, e.g., Fact Sheet, supra note 37 ("ERISA protects retirement savings from mismanagement and abuse, and clarifies that those in charge of those savings be held to a high standard - that is, they must act in the best interests of plan participants. It also requires transparency and accountability, ensuring that participants have access to information about their plans. More than half of America's workers earn health benefits on the job, and ERISA protects those too, as well as other employee benefits."). 
Despite this focus on retirement benefits, ERISA also affected employer-sponsored health plans ${ }^{47}$ though "some have viewed ERISA's regulations governing employee health coverage as an unintended consequence of the statute." ${ }^{48}$ Because, in contrast to retirement plans, health plans did not involve large sums of deferred employee pay, Congress did not have to worry about a massive loss of expected future benefits from a lack of plan funding. ${ }^{49}$ As a result, ERISA does not require health plans to offer any particular benefits, ${ }^{50}$ but it does require both retirement-plan and health-plan SPDs to satisfy the same readability standard when disclosing benefits to participants. ${ }^{51}$

However, the differences between retirement plans and health plans support different disclosure practices. First, retirement benefits and health benefits operate differently. Retirement benefits are concerned with deferred compensation and investments, ${ }^{52}$ while health benefits are concerned with splitting the costs for covered health services between a participant and the plan. ${ }^{53}$ Unlike retirement plans, which can identify either an account balance or benefit amount, ${ }^{54}$ health plans can only identify the formula for calculating a participant's or the plan's costs for health-care categories - e.g., "diagnostic tests" or "hospitalization." Plans cannot guarantee the actual cost for any particular health service

47. ERISA § 3(3), 29 U.S.C. § 1002(3) (including "employee welfare benefit plan" in the definition of "employee benefit plan").

48. Kathryn E. Diaz, There Is No Plain Meaning: The Jurisprudence of ERISA and the Exclusive Benefit Rule, 4 U. PA. J. LAB. \& EmP. L. 71, 86 (2001).

49. WiedenBECK, supra note 33, at 16.

50. See supra notes 38-39 and accompanying text.

51. See ERISA § 102 (establishing one SPD requirement).

52. See generally Employee Benefits Security Administration, What You Should Know About Your Retirement Plan, U.S. DePt. OF LAB. (Sept. 2, 2020), https://www.dol.gov/sites/dolgov/files/ebsa/about-ebsa/ouractivities/resource-center/publications/what-you-should-know-about-yourretirement-plan.pdf [https://perma.cc/5DRM-HPJ4].

53. See, e.g., Walmart, Inc., supra note 19, at 47-49, 54-65 (showing how costs in the plan are split between participants and the plan).

54. Cf. Employee Benefits Security Administration, supra note 52, at 14 ("If you are in a defined benefit plan, you will receive an individual benefit statement . . . Review its description of the total benefits you have earned and whether you are vested in those benefits.... Defined contribution plans, including 401(k) plans, also must send participants individual benefit statements ....").

55. See, e.g., Walmart, Inc., supra note 19, at 47. 
because costs vary across providers ${ }^{56}$ and depend on how the provider codes the service when it bills the plan. ${ }^{57}$

Second, health-plan disclosures often involve more than just one benefit. Plan sponsors could offer numerous benefits under a single plan, including medical, dental, vision, disability, life insurance, critical illness, and other benefits - each with its own eligibility requirements. ${ }^{58}$ As a result, health-plan SPDs can be lengthy and complex to navigate. ${ }^{59}$

Finally, the participant experience when utilizing medical benefits is likely to be different than the retirement-benefit experience. Until retirement, participants contributing to defined-contribution planslike 401(k) plans - may be concerned with their deferred payroll costs, investment options, and possibly loans from their individual accounts. ${ }^{60}$ In defined-benefit pension plans, participants may have even fewer dayto-day concerns about plan operation since the plan guarantees benefits and participating employers must fund the plan. ${ }^{61}$ In contrast, health benefits might require a participant to choose between multiple plans each year-potentially, each with its own deductible level, provider network, and plan type - and to determine whether to enroll family members. ${ }^{62}$ And participants may need to utilize their health benefits at least on an annual basis, which means that they are consistently concerned with out-of-pocket medical costs. ${ }^{63}$ Additionally, different

56. David Newman, Stephen T. Parente, Eric Barrette \& Kevin Kennedy, Prices for Common Medical Services Vary Substantially Among the Commercially Insured, 35 HeAlth Affs. 923, 923 (2016); see Vineet Arora, Christopher Moriates \& Neel Shah, The Challenge of Understanding Health Care Costs and Charges, 17 Am. Med. Ass'N J. EThics 1046, 1047 (2015) ("Even if the doctor knew the charge, he or she would be unlikely to know the specifics of a particular patient's insurance plan.").

57. See generally What Is Medical Billing?, AAPC, https://www.aapc.com/ medical-billing/medical-billing.aspx [https://perma.cc/JP2K-JU4T] (last visited Jan. 5, 2021) ("The main responsibility of a medical coder is to review clinical statements and assign standard codes . . . . Medical billers, on the other hand, process and follow up on claims sent to health insurance companies for reimbursement of services rendered by a healthcare provider."). Though plans that charge copays instead of split payments for some services can guarantee a flat cost for those services, the plans still cannot guarantee how a provider will bill any given healthcare service. $C f$. $i d$.

58. See, e.g., WALMART, InC., supra note 19, at 13-17.

59. See infra notes 137-43 and accompanying text.

60. Employee Benefits Security Administration, supra note 52, at 3, 17.

61. Id. at 3 .

62. See, e.g., WALmart, Inc., supra note 19, at 46.

63. See Fred Backus \& Jennifer De Pinto, Americans More Concerned About Health Care Costs than Universal Coverage - CBS News Poll, CBS News (Oct. 18, 2019), https://www.cbsnews.com/news/americans-more-concerned- 
benefits require different terminology to adequately explain them, though various health and welfare benefits ${ }^{64}$ may share common terms, like deductible and copayment. .5 $^{5}$

Therefore, given the differences between retirement benefits and health benefits, disclosure practices for each benefit merit separate discussion. ${ }^{66}$ This Note considers how the SPD requirements might be modified to better protect health-and-welfare-plan participants.

\section{B. SPD Background and Requirements}

When passed, ERISA was a "consumer protection bill" that allowed participants to rely on their reasonable expectations of promised benefits. ${ }^{67}$ Congress wanted to empower participants through disclosure ${ }^{68}$ and the SPD was intended to manifest that goal.

about-health-care-costs-than-universal-coverage-cbs-news-poll/ [https:// perma.cc/NSE8KM57].

64. The phrase health and welfare benefits refers to medical, dental, vision, life, long-term care and disability insurances, as well as other nonretirement benefits. About Health and Welfare Plans, AICPA, https://www.aicpa.org/interestareas/employeebenefitplanauditquality/re sources/accountingandauditingresourcecenters/abouthealthandwelfarepla ns.html\#: :text=Health\%20and\%20welfare\%20benefit\%20plans,tuition\% 20assistance\%2C\%20day\%2Dcare\%2C [https://perma.cc/6PMJ-TGXZ] (last visited Jan. 4, 2021). But ERISA refers to covered nonretirement benefits as "welfare benefit plan[s]," ERISA § 3(1), 88 Stat. 829, 833 (1974) (codified as amended at 29 U.S.C. $§ 1002(1)$ ), so some attorneys also refer to health and welfare benefits as welfare benefits. See, e.g., Edward G. Hammond, Employee Benefits/ERISA $\&$ Compliance, CLARK HILL, https://www.clarkhill.com/contents/employee-benefits-erisa-services [https://perma.cc/AB7D-S9D4] (last visited Jan. 4, 2021). Of course, welfare benefits can also be used to refer to state-provided welfare, which is unrelated to employee benefit plans under ERISA. Government Benefits, USA.GOV, https://www.usa.gov/benefits [https://perma.cc/6XTPFBDG] (last updated Sept. 10, 2020). No doubt, this linguistic uniformity adds to the confusion over insurance terminology.

65. Compare Walmart, Inc., supra note 19, at 47-49, with id. at 235-49.

66. Notably, the Advisory Council on Employee Welfare and Pension Benefit Plans, when asked to review benefit communications, created separate reports for health and welfare plan communications and retirement communications. Compare Advisory Council, supra note 25, with Advisory Council on Employee Welfare and Pension Benefit Plans, Advisory Council Report of the Working Group on Communications to Retirement Plan Participants, U.S. DeP'T OF LAB., https://www.dol.gov/agencies/ebsa/ about-ebsa/about-us/erisa-advisory-council/2005-communications-toretirement-plan-participants [https://perma.cc/WP5Z-9SDK] (last visited Jan. 6, 2021).

67. See Cummings, supra note 43, at 383 (noting that ERISA accomplished Congress's underlying consumer-protection goals).

68. $\quad$ ERISA $\S 2(a), 29$ U.S.C. § 1001(a). 
ERISA requires each employee-benefit plan to "be established and maintained pursuant to a written instrument"-called a plan document. ${ }^{69}$ Plan documents are comprehensive and lay out a plan's legally binding terms. ${ }^{70}$ Given the complexity of health benefits, plan documents are almost inscrutable, and a reader likely needs legal knowledge to interpret them correctly. ${ }^{71}$ Unsurprisingly, Congress was concerned that the average plan participant would be unable to understand the terms of their own benefits, making it impossible for those participants to rely on the documents or to hold the plan administrator to the plan's terms. ${ }^{72}$

Congress created the SPD as a remedy for the plan document's unreadability. ${ }^{73}$ To be useful, "the SPD must summarize by simplifying

69. Id. $\S 402(\mathrm{a})(1)$. In practice, multiple documents may be used to create the plan document. WIEDENBECK, supra note 33, at 78 .

70. CIGNA Corp. v. Amara, 563 U.S. 424, 436-37 (2011) (explaining that ERISA allows participants to recover only under the plan's terms, as described in the plan's "written instrument" (citing ERISA, Pub. L. No. 93-406, § 502(a)(1)(B))).

71. WiEDENBECK, supra note 33, at 96 ("Benefit plan documents are complex legal instruments, often running over thirty pages in length, the precise meaning of which can only be determined by giving scrupulous attention to a set of defined terms, and following up a large number of internal cross-references.").

72. See H.R. Rep. No. 93-533, at 8 (1973), reprinted in 1974 U.S.C.C.A.N. 4639,4646 ("An important issue relates to the effectiveness of communication of plan contents to employees. Descriptions of plans furnished to employees should be presented in a manner that an average and reasonable worker participant can understand intelligently. It is grossly unfair to hold an employee accountable for acts which disqualify him from benefits, if he had no knowledge of these acts, or if these conditions were stated in a misleading or incomprehensible manner in plan booklets. Subcommittee findings were abundant in establishing that an average plan participant, even where he has been furnished an explanation of his plan provisions, often cannot comprehend them because of the technicalities and complexities of the language used."); S. Rep. No. 93127, at 11 (1973), reprinted in Internal Revenue Serv., C.B. 1974-3 Supplement, Committee Reports and Congressional Record Excerpt Relating to: Public Law 93-406 Employee Retirement Income Security Act of 1974, at 11 (1974) (using the same language as the House report); see ERISA § 2(b), Pub. L. No. 93-406, 88 Stat. 829, 832 (codified as amended at 29 U.S.C. $\S 1001$ (b) ("It is hereby declared to be the policy of this Act to protect . . . the interests of participants in employee benefit plans and their beneficiaries, by requiring the disclosure and reporting to participants and beneficiaries of financial and other information with respect thereto ...").

73. See WIEDENBECK, supra note 33, at 72 ("Participants' principal source of information about the terms of the plan is the summary plan description (SPD)."). 
and omitting detail." ${ }^{74}$ Perhaps paradoxically, the SPD must also be "comprehensive," 75 and include a benefits description and any benefit conditions or limitations. ${ }^{76}$ But the SPD must also include information that does not help participants understand or utilize their benefits, including plan subrogation rights, disclaimers regarding plan termination and amendment, COBRA continuation-coverage rights, ${ }^{77}$ and the source of plan contributions. ${ }^{78}$ Additionally, several legal notices add more clutter to the SPD. ${ }^{79}$ They are included either because the law requires them to be in the SPD, or because it is easier for the plan administrator to distribute the notices in the SPD rather than separately. ${ }^{80}$

The plan administrator is responsible for distributing the SPD to participants by various deadlines, with the time for distribution

74. Id. at 96 (citing Hansen v. Cont'l Ins. Co., 940 F.2d 971, 982 (5th Cir. 1991), abrogated on other grounds by Amara, 563 U.S. 421).

75. 29 U.S.C. $\S 1022(\mathrm{a}) ;$ Hansen, 940 F.2d at 982.

76. 29 C.F.R. $\S 2520.102-3(j)(3)$ (2020). When a court determines which document constitutes the SPD, the court may look "to see whether [the document] contains all or substantially all categories of information required" by law. Hicks v. Fleming Cos., Inc., 961 F.2d 537, 542 (5th Cir. 1992).

77. COBRA continuation coverage was originally created by the Consolidated Omnibus Budget Reconciliation Act of 1985 ("COBRA"). Pub. L. No. 99272,110 Stat. 82 . When a plan meets certain requirements, the plan must offer COBRA continuation coverage to plan participants and beneficiaries after they lose coverage under the plan. 26 U.S.C. § 4980B(f)(2). Plans must distribute an initial notice when non-COBRA coverage begins and then a separate notice when the participant or beneficiary becomes eligible for COBRA continuation coverage. 26 U.S.C. $\$ 4980 \mathrm{~B}(\mathrm{f})(6)$. For an example of COBRA information included in an SPD, see, e.g., WALMART, INC., supra note 19, at 123-29.

78. 29 C.F.R. $\S 2520.102-3$ (2020).

79. See, e.g., Walmart, Inc., supra note 19, at 284-91 (including HIPAA privacy notice, Medicare creditable-coverage notice, and Children's Health Insurance Program (CHIP) notice); Harvard University, Summary Plan Description: Health and Welfare Plans 46-59 (2022), https://hr.harvard.edu/files/humanresources/files/healthwelfare_benefit _summaryplandescription.pdf [https://perma.cc/768M-3M8R] (including genetic nondiscrimination notice, HIPAA portability notice, HIPAA privacy notice, mental-health-parity notice, newborn-coverage notice, and several other notices).

80. See Employee Benefits Security Administration, Reporting and Disclosure Guide for Employee Benefit Plans 2-8 (2017), https:// www.dol.gov/sites/dolgov/files/EBSA/about-ebsa/our-activities/resourcecenter/publications/reporting-and-disclosure-guide-for-employee-benefitplans.pdf [https://perma.cc/EL4X-A89L]. 
dependent on why the administrator is issuing the SPD. ${ }^{81}$ But the penalties for failing to deliver an SPD are limited. If a participant requests an $\mathrm{SPD}$, the plan must provide it within thirty days or else face a $\$ 110$ penalty, maximum, for each day the SPD is late. ${ }^{82}$ Additionally, a person or entity that "willfully" fails to distribute an SPD could face criminal charges ${ }^{83}$ though criminal enforcement under ERISA seems focused on restoring plan assets rather than enforcing SPD distribution. ${ }^{84}$ Also, despite these enforcement mechanisms, plan sponsors that rarely consult an employee-benefits attorney-such as small employers with a fully insured plan - may not even be aware that they need an SPD and, consequently, may never create or distribute one. ${ }^{85}$

Complementing its comprehensive SPD content and disclosure requirements, ERISA also contains a readability requirement. To satisfy the law, an SPD "shall be written in a manner calculated to be understood by the average plan participant, and shall be sufficiently accurate and comprehensive to reasonably apprise such participants and beneficiaries of their rights and obligations under the plan." ${ }^{166}$ The

81. 29 C.F.R. $\S 2520.104 b-2$ (2020) provides SPD delivery requirements. 29 C.F.R. $\S 2520.104 b-3$ (2020) provides how and when to notify plan participants of plan changes.

82. 29 U.S.C. $\$ 1132$ (listing $\$ 100$ as the maximum daily penalty); 29 C.F.R. $\S 2575.502 \mathrm{c}-1$ (2020) (updating the maximum daily penalty to $\$ 110$ ).

83. 29 U.S.C. $\S 1131$.

84. Employee Benefits Security Administration, Fact Sheet Outlining Criminal Enforcement Under ERISA 1 \& n.1 (2021), https://www.dol.gov/sites/dolgov/files/ebsa/about-ebsa/our-activities/ resource-center/fact-sheets/ebsa-monetary-results.pdf [https://perma.cc/ VZM9-ZSCH].

85. This assertion is based in part on the author's own experience in the employee-benefits industry. The author looked for survey data on how many employers had SPDs but, unsurprisingly, could not find anyemployers and their industry partners have few incentives to admit to failing to provide a legally required document. However, the author's experiences are backed up by the plethora of advice to fully insured plans that they must be certain to provide a true SPD to participants and must be wary of relying on insurance certificates to meet their legal obligations. See, e.g., What is the Difference between a Plan Document and a Summary Plan Description?, SHRM (June 14, 2021), https://www.shrm.org/ resourcesandtools/tools-and-samples/hr-qa/pages/whatsthediffbetween plandocsandasummaryplandescription.aspx [https://perma.cc/UB6T-CLPE] ("Confusion often arises for employers with fully insured plans as the insurance carrier does not provide the ERISA plan document or the SPD. This is the responsibility of the plan administrator. The insurance carriers typically provide employers with a master contract, certificate of coverage or summary of benefits, and employers may mistakenly assume this meets the ERISA requirement.").

86. $\quad$ ERISA $\S 102,29$ U.S.C. $§ 1022$. 
corresponding federal regulation reiterates this standard and then elaborates in similarly vague terms:

In fulfilling these requirements, the plan administrator shall exercise considered judgment and discretion by taking into account such factors as the level of comprehension and education of typical participants in the plan and the complexity of the terms of the plan. Consideration of these factors will usually require the limitation or elimination of technical jargon and of long, complex sentences, the use of clarifying examples and illustrations, the use of clear cross references and a table of contents. ${ }^{87}$

The inherent tension between the SPD's competing purposescomprehensive disclosure and readable summary - can result in an SPD that is either ineffective ${ }^{88}$ or, perhaps worse, misleading. ${ }^{89}$ And despite the statutory and regulatory readability requirements, SPDs are not meeting the needs of Americans, who generally have trouble understanding their SPDs. ${ }^{90}$

\section{Employee Health Literacy in CRisis}

The last major health-literacy study of American adults was conducted by the Department of Education in 2003, in the "National Assessment of Adult Literacy." "91 The Department administered the National Assessment to 19,000 Americans age 16 and older. ${ }^{92}$ Other studies and surveys have been conducted since the National Assessment, but they have focused on narrower populations. ${ }^{93}$ So the National Assessment continues to be authoritatively cited, even though

87. 29 C.F.R. $§ 2520.102-2(\mathrm{a})$ (2020). The regulations do create one specific readability requirement: plans with a certain concentration of non-English speakers must provide those participants the opportunity to learn about benefits in their native language. Id. $\S 2520.102-2(\mathrm{c})$.

88. Advisory Council, supra note 25.

89. See Washington v. Murphy Oil USA, Inc., 497 F.3d 453, 456 (5th Cir. 2007) ("This effort at simplification, however, often produces situations in which the terms of the SPD conflict with the more detailed terms of the plan.").

90. See infra Part II.

91. See generally KUTNER ET AL., supra note 3. See supra note 9.

92. Kutner ET AL., supra note 3, at iii.

93. E.g., Donald Rubin, A Health Literacy Report: Analysis of 2016 BRFSS HeALTh Literacy Data 3 (2016) (noting that survey data was "derived from a 3-question optional health literacy module authorized for inclusion in the Behavioral Risk Factor Surveillance System."), https://www. cdc.gov/healthliteracy/pdf/Report-on-2016-BRFSS-Health-Literacy-DataFor-Web.pdf [https://perma.cc/N59H-Q3RM]; UnITEDHEALTHCARE, supra note 7 , at 2 (surveying only 1,006 adults). 
close to two decades have passed, and even though the Affordable Care Act was adopted in the interim..$^{94}$

Additionally, while insurance carriers have conducted their own health-literacy surveys and studies, those reports may not allow readers to compare the health literacy of different groups of Americans. ${ }^{95}$ As this Part explores, though, health literacy in America is poor across all groups ${ }^{96}$ so, while this Note uses the National Assessment as a starting point, ${ }^{97}$ it will reference later industry research to verify that American health literacy has remained stagnant since the National Assessment. ${ }^{98}$

\section{A. Employee Health Literacy}

Rather than ask respondents to gauge their own health literacy, the National Assessment "measured literacy directly through tasks completed by adults." 99 The Assessment used four categories to describe health literacy: below basic, basic, intermediate, and proficient. ${ }^{100}$ Proficient literacy included the ability to "[c]alculate an employee's share of health insurance costs for a year" and "evaluate information to

94. See supra note 9 .

95. See, e.g., Masterson, supra note 7 (summarizing UnitedHealthCare, supra note 7 , at 13$)$.

96. See infra note 102 and accompanying text.

97. Given the National Assessment's age, the government should conduct a new national health literacy assessment. However, since SPDs were introduced into law by ERISA in 1974, which was more than 29 years before the National Assessment, it seems unlikely that much would have improved due to SPDs in the years between the National Assessment and this Note's publication, especially given that health insurance has become increasingly more complex. See CommitTeE on Employer-BASED Health Benefits, Employment and Health Benefits: A Connection AT Risk 87 (Marilyn J. Field \& Harold T. Shapiro eds., 1993) ("The persistent escalation of health benefit costs has prompted employers to become ever more involved in the design and management of their health benefit plans and to experiment with an ever-wider variety of techniques in an effort to contain their costs.").

98. The National Assessment focused on health literacy, Kutner ET AL., supra note 3 , at iii, so additional research is needed to determine if participants are having the same problems understanding other benefits, such as life and disability insurances. This is important as plan administrators may combine their health and welfare benefits into one SPD. E.g., Walmart, InC., supra note 19, at 1.

99. KutNer ET AL., supra note 3, at iii.

100. Id. at 5. Below basic literacy covered respondents who were "nonliterate in English" or whose primary literary ability was "locating" information; basic literacy covered respondents who could "perform simple and everyday literacy activities"; intermediate literacy covered respondents who could "perform moderately challenging literacy activities"; and proficient literacy covered respondents who could "perform more complex and challenging literacy activities." $I d$. 
determine which legal document is applicable to a specific health care situation"101_both are tasks that would require an individual with employer-sponsored insurance to reference their SPD or other employerprovided summaries.

Rather than describe the results, this graphic reproduced from the National Assessment best communicates them: ${ }^{102}$

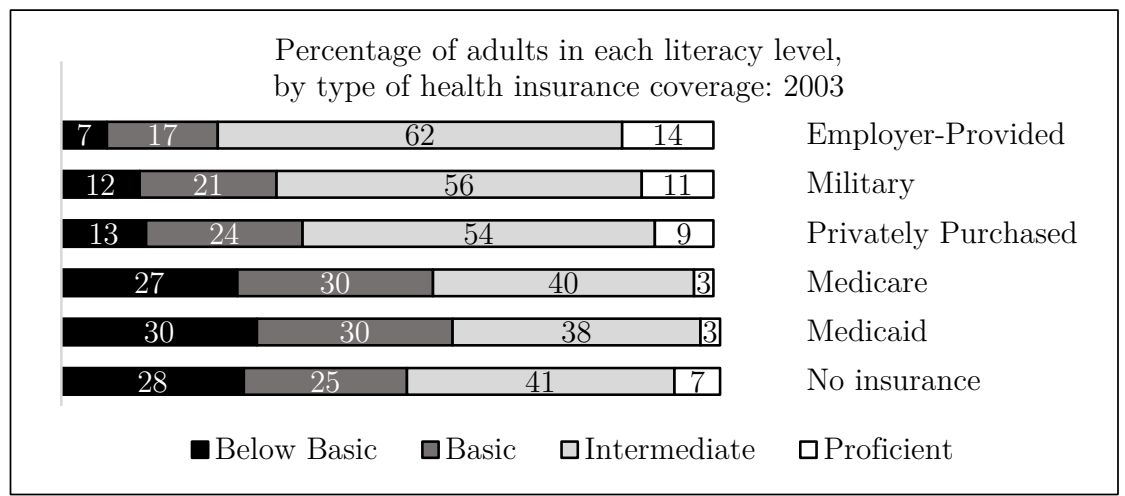

The results show that only $14 \%$ of respondents with employerprovided insurance had proficient literacy, which means that $86 \%$ of respondents with employer-provided insurance would likely be unable to calculate their insurance costs or sort through several insurance documents. ${ }^{103}$

The National Assessment did not attempt to explain why participants with employer-sponsored insurance were more likely to

101. Id. at 6. The National Assessment tested three "literacy scales": prose, document, and quantitative. Id. at 2. Most relevant to this Note is document literacy, which includes the ability to "search, comprehend, and use information from noncontinuous texts in various formats," $i d$., because SPDs contain potions of noncontinuous text and use various formats. See, e.g., Walmart, InC., supra note 19.

102. Id. at 18. Though a breakdown of literacy by gender and race are outside this Note's scope, it is worth noting that women scored higher than men in every insurance category except respondents with privately purchased insurance, and white respondents scored much higher than Black and Hispanic respondents in every category. Id. at 50. For perspective, the lowest literacy score for white respondents was 222, for those with Medicare, and the highest was 266, for those with employer-provided insurance, whereas the highest literacy score for Black respondents was 226 and for Hispanic respondents was 229, for those with employerprovided insurance. Id. Additionally, wealthier respondents had higher literacy scores than poorer respondents. $I d$. at 14 .

103. See $i d$. at 18 . This assertion states that the respondents would "likely be unable" to complete these tasks because the National Assessment is unclear: the Assessment could have assigned a respondent intermediate or worse literacy because the respondent performed poorly overall, even though the respondent may have performed well on some documentliteracy questions. See $i d$. at 2-3. Twelve of the twenty-eight questions in the National Assessment were document-literacy questions. Id. at 3. 
have higher literacy. The improved scores could be the result of employer-provided SPDs and other benefits communication, but they could also be the result of other unknown variables. ${ }^{104}$ For instance, more educated individuals are more likely to find employment, ${ }^{105}$ and more educated respondents were generally more likely to score higher on the National Assessment than lower educated respondents ${ }^{106}$ - so increased education outside employment could be the reason for better literacy.

But even if SPDs caused the improved scores, the National Assessment's results would imply that SPDs have limited impact because, while respondents with employer-provided insurance have better health literacy overall, the overwhelming majority of respondents in all categories were not proficient. ${ }^{107}$ Therefore, at best, SPDs improve health literacy only marginally. This would align with research showing that SPDs are not helpful. ${ }^{108}$

The National Assessment can also be used as a tool for determining the impact of poor health literacy. Using the National Assessment data, experts estimated that the cost of poor health literacy in the United States is between $\$ 106$ billion and $\$ 238$ billion annually. ${ }^{109}$ When taking into account future costs, "the real present day cost of low health literacy is closer in range to $\$ 1.6$ trillion to $\$ 3.6$ trillion." 110 Though

104. Id. ("The purpose of this report is to examine the relationship between health literacy and various self-reported background factors. This report is purely descriptive in nature. Readers are cautioned not to draw causal inferences based solely on the results presented here. It is important to note that many of the variables examined in this report are related to one another, and complex interactions and relationships have not been explored here.").

105. U.S. Bureau of Lab. Stat., OOChart: More Education, Less Unemployment, Occupational Outlook Q., Spring 2014, at 47 https://www.bls.gov/ careeroutlook/2014/spring/oochart.pdf [https://perma.cc/ F24T-8KJA].

106. Kutner ET AL., supra note 3, at 43.

107. See supra notes 102-03 and accompanying text.

108. Medill et al., supra note 26 , at 8 ("The results of the study suggest that, based on the difficulties encountered by the expert readers, important information conveyed through a summary plan description may be difficult for the average plan participant to identify reliably. Once identified, the language used to convey important information in the summary plan description document may be written at a level that is too high for its intended audience - the 'average plan participant' - to understand. In other words, the primary communication tool used to provide important information to workers who participate in their employer's health care plan often may be unreadable to them.").

109. VERNON ET AL., supra note 1, at 6. These estimated costs appear to include increased costs to individuals, which in turn means increased costs for the insurers covering those indviduals. See $i d$. at 4-6.

110. Id. 
these numbers are only estimates based on 2006 American health spending, they are useful to show the potential monetary impact of low health literacy. ${ }^{111}$ The cost alone is motivation to tackle poor health communications, but poor health literacy is also associated with worse health outcomes ${ }^{112}$ (which may be a primary driver of the high cost of low health literacy $\left.{ }^{113}\right)$. Accordingly, National Assessment respondents who indicated that they had poor overall health also had the lowest literacy scores. ${ }^{114}$ Therefore, reforms aimed at helping Americans understand their health care might reduce costs and improve health outcomes. Given that Americans with employer-provided insurance likely have only marginally better health literacy, ${ }^{115}$ they would benefit from disclosure reform as much as Americans with other insurance plans.

Recent industry studies confirm that American health literacy continues to be a problem. As noted in the Introduction, UnitedHealthcare found that only $9 \%$ of its study respondents could define four basic health-insurance terms. ${ }^{116}$ In a study by the Kaiser Family Foundation, only $51 \%$ of respondents were able to calculate their hypothetical out-of-pocket costs for a hospital bill when provided with a plan's copay and deductible. ${ }^{117}$ Additionally, when asked directly

111. Id. at 6,14 .

112. Darren A. DeWalt \& Michael P. Pignone, The Role of Literacy in Health and Health Care, 72 Am. FAm. Physician 387, 387 (2005) (citing Darren A. DeWalt, Nancy D. Berkman, Staey Sheridan, Kathleen N. Lohr \& Michael P. Pignone, Literacy and Health Outcomes: A Systematic Review of the Literature, 19 J. Gen. Intern. Med. 1228, 1236 (2004)); Kutner ET AL., supra note 3, at 44.

113. DeWalt \& Pignone, supra note 112, at 388 (first citing U.S. DEP'T of Health and Hum. Serv., Healthy People 2010: Understanding AND IMPROving HEALTh 56 (2d ed. 2000), https://www.healthypeople.gov/ 2010/Document/pdf/uih/2010uih.pdf [https://perma.cc/Y4EX-BCXY]; and then citing COMm. ON IDENTIFyIng Priority Areas For QuAlity Improvement, Inst. of Medicine, Priority Areas for National Action: Transforming Health Care Quality 46, 52-53 (Karen Adams \& Janet M. Corrigan eds., 2003)).

114. Kutner ET AL., supra note 3, at 48.

115. See supra notes $102-03$ and accompanying text.

116. UnitedHeALthCARE, supra note 7 , at 13 ; see supra text accompanying note 7 . Another industry survey found that only $38 \%$ of insured respondents could define three basic health-insurance terms: copay, premium, and deductible. Hanna Horvath, Policygenius, Health Insurance Literacy Survey 2020: Data Highlights, 9 (2020) https://assets. ctfassets.net/3uw9cov4u60w/Oe30cni5ZPbOOlhPC65Ea/3192cef6e5bc15 db386e8e8a661ad090/Health_Insurance_Literacy_Survey_2020.pdf [https://perma.cc/HYJ9-DCM2].

117. Mira Norton, Liz Hamel \& Mollyann Brodie, Assessing Americans' Familiarity with Health Insurance Terms and Concepts, KAISER FAM. 
in another carrier survey, 35\% of employed respondents indicated that they "either somewhat understand, don't understand or know nothing about their healthcare coverage." 118 Though $35 \%$ might seem like a low number, remember that one industry survey found that $96 \%$ of respondents overestimated their own "understanding of health insurance concepts." 119 Therefore, asking employees to self-report their own confusion might produce inaccurate results.

This confusion regarding benefits has continued while employerprovided insurance has become more inadequate for consumers' needs. ${ }^{120}$ And even though continuing poor health literacy affects health-care costs and outcomes, ${ }^{121}$ health literacy has not been given substantial attention in national healthcare reform. As a country, lawmakers have instead focused on reforming the healthcare system

Found. (Nov. 11, 2014), https://www.kff.org/health-reform/poll-finding/ assessing-americans-familiarity-with-health-insurance-terms-and-concepts / [https://perma.cc/3RJM-CQ7T]. The study asked respondents "to calculate how much they would have to pay for a 4-day hospital stay with a $\$ 1000$ deductible and $\$ 250$-per-day copay." Id. The study also asked respondents to "calculate how much they would have to pay for an out-of-network lab test when the insurer pays $60 \%$ of allowed charges," and only $16 \%$ of respondents correctly answered that question. Id.

118. Maestro Health, What Employees Are Thinking About Their HealthCARE (Nov. 2018), available for download at https://www. maestrohealth.com/resource/what-employees-think-about-healthcareinfographic/ [https://perma.cc/S3ZX-ARAT]. The survey is unclear about whether the "1,000 employed consumers" that were surveyed were Maestro Health consumers or a more nationally or regionally representative sample. $I d$.

119. 4 Basic Health Insurance Terms $96 \%$ of Americans Don't Understand, supra note 10.

120. See Sara R. Collins, Munira Z. Gunja \& Gabrielle N. Aboulafia., U.S. Health Insurance Coverage in 2020: A Looming Crisis in AfFordability 5 (2020), https://www.commonwealthfund.org/sites/ default/files/2020-08/Collins_looming_crisis_affordability_biennial_ 2020_sb.pdf [https://perma.cc/NP7J-8KWQ] (showing that $17 \%$ of respondents with employer-provided insurance were underinsured in 2010 while $26 \%$ of respondents were underinsured in 2020). Unfortunately, the ACA's passage is correlated with an increase in the number of Americans with inadequate employer-provided insurance, even while, on the positive side, the ACA's passage is also correlated with an increase in the insured population and shortened coverage gaps. Sara R. Collins, Herman K. Bhupal \& Michelle M. Doty, Health Insurance Coverage Eight Years After the ACA: Fewer Uninsured Americans and Shorter Coverage Gaps, But More Underinsured 1-2 (2019), https://www. commonwealthfund.org/sites/default/files/2019-08/Collins_hlt_ins_ coverage_8_years_after_ACA_2018_biennial_survey_sb_v2.pdf [https://perma.cc/6T63-4QCP].

121. See supra notes 109-14 and accompanying text. 
directly. ${ }^{122}$ One exception to lawmakers' focus on the U.S. healthcare system is the ACA's Summary of Benefits and Coverage - commonly called an SBC. ${ }^{123}$ Along with ERISA's SPD requirement, each employersponsored health plan must produce and distribute an SBC, which is a standardized benefits summary. ${ }^{124}$ An SBC helps participants compare their plan's medical benefits against other medical plans, such as plans sold on a health-insurance marketplace or offered to a spouse by the spouse's employer. ${ }^{125}$

122. See Laxmaiah Manchikanti, Standiford Helm II, Ramsin M. Benyamin \& Joshua A. Hirsch, Evolution of US Health Care Reform, 20 PAIN PHYSICIAN 107, 107 (2017) ("Health care reform generally attempts to broaden the population that receives health care coverage, expand the array of health care providers, improve access to health care specialists, improve the quality of health care, and, finally, decrease the cost of health care."). Several people who reviewed drafts of this Note asked whether reducing the complexity of the U.S. health system by moving away from the private insurance model was a better way to control costs. There is plenty of scholarship on the topic. E.g., Michael Chernew \& Harrison Mintz, Administrative Expenses in the US Health Care System: Why So High?, 326 J. Am. Med. Ass'N 1679 (2021); Christopher Cai, Jackson Runte, Isabel Ostrer, Kacey Berry, Ninez Ponce, Michael Rodriguez, Stefano Bertozzi, Justin S. White \& James G. Kahn, Projected Costs of Single-Payer Healthcare Financing in the United States: A Systematic Review of Economic Analyses, PLOS MEDICINE (Jan. 15, 2020), https://journals.plos.org/plosmedicine/article?id=10.1371/journal.pmed. 1003013 [https://perma.cc/HWT8-KU4K] (arguing that data supports that a single-payer healthcare system would be cheaper than the United States' current system). But Congress's attempts to reform the healthcare system stalled under President Trump, see Julie Rovner \& Phil Galewitz, Promises Kept? On Health Care, Trump's Claims of 'Monumental Steps' Don't Add Up, Kaiser Health News (Sept. 28, 2020), https://khn.org/ news/promises-kept-on-health-care-trumps-claims-of-monumental-stepsdont-add-up/ [https://perma.cc/TS3R-J9E6], and President Biden does not support completely reforming the system, see Health Care, BIDENHARRIS, https://joebiden.com/healthcare/ [https://perma.cc/V7ETH6AK] (last visited Dec. 28, 2020) ("[Joe Biden] opposes every effort to get rid of [the ACA] . ..."). Improving health disclosures is potentially another way to help reduce costs, and it has the added benefit of educating Americans on a healthcare system that seems unlikely to drastically change for the foreseeable future.

123. ACA, Pub. L. No. 111-148, sec. 1001, § 2715(a), 124 Stat. 132 (2010) (codified as amended at 42 U.S.C. $\S 300 \mathrm{gg}-15(\mathrm{a})$ ).

124. 42 U.S.C. $\S 300$ gg-15. For specific SBC requirements, see 29 C.F.R. $\S 2590.715-2715(2020)$.

125. Summary of Benefits and Coverage, HealthCare.gov, https://www. healthcare.gov/health-care-law-protections/summary-of-benefits-andcoverage/ [https://perma.cc/N6TS-J3P3] (last visited Jan. 4, 2021). SBCs are only required for medical plans, so employees need to look at other summaries, such as an SPD, for non-medical benefits. 42 U.S.C. § 300gg$15(\mathrm{a})$. 
But those standardized SBCs exacerbate the problems found in SPDs because they lack tailoring. ${ }^{126}$ The SBC's uniform glossarywhich creates uniform definitions for common health insurance terms $^{127}$ - is also a generic document that is not tailored to a plan's terms or other communications. ${ }^{128}$ And SBCs do not replace the SPD or plan document, making the SBC another document that participants could read but cannot rely on. ${ }^{129}$ Therefore, even the one recent attempt at improving employee health literacy did not provide a remedy for some of the health-literacy problems plaguing the American worker. ${ }^{130}$ Despite the common practice of creating standardized employee disclosures, ${ }^{131}$ these uniform plan communications cannot meet the

126. See 42 U.S.C. $§ 300 \mathrm{gg}-15$ (b) ("The standards shall ensure that the summary of benefits and coverage is presented in a uniform format . . ." (emphasis added)); 29 C.F.R. § 2590.715-2715(a)(2)(i) (2020) ("[T]he SBC must include the following: (A) Uniform definitions of standard insurance terms and medical terms .....").

127. 29 C.F.R. $\S 2950.715-2715$ (c) (2020).

128. See id. $\S(\mathrm{c})(3)$. For a thorough discussion of the failings of the SBC uniform glossary, see Anna Crane, Note, Lost in Translation: The Affordable Care Act's Attempt to Make Insurance-Speak Understandable, 81 Geo. Wash. L. Rev. 556, 572-78 (2013).

129. See 42 U.S.C. § 300gg-15(b)(3) ("The standards shall ensure that the summary of benefits and coverage includes ... (H) a statement that the outline is a summary of the policy or certificate and that the coverage document itself should be consulted to determine the governing contractual provisions ...."). For a look at how SBCs compare to SPDs, compare the Walmart SBC, Walmart, InC., Summary of Benefits and Coverage: What this Plan Covers \& What you Pay for Covered Services (2021), https://one.walmart.com/content/dam/ themepage/pdfs/sbc-Premier-National-Offering-2021.pdf [https://perma.cc/ AZ6W-XS67], with the Walmart SPD, WALMART, InC., supra note 19, at 47 .

130. When surveyed by one consumer group, a majority of respondents found the SBC helpful when they used it to "select the best health plan available." Lynn Quincy, EARly Experience With a NeW Consumer Benefit: The Summary of Benefits And Coverage 11 (2013), https://advocacy.consumerreports.org/wp-content/uploads/2013/03/ Early_Experience_Report.pdf [https://perma.cc/G4D7-WZJW]. So uniformity in format might be beneficial to some participants in some circumstances - for instance, when participants need to compare health plans offered by different sources. More research is needed regarding the SBC's impact on health literacy - and ideally, that research would separate out the impact by various background circumstances, as the National Assessment did. KUTNER ET AL., supra note 3, at 8.

131. See, e.g., Workplace Posters, U.S. DeP'T OF LAB., https://www.dol.gov/ agencies/whd/posters [https://perma.cc/RST4-B5DN] (last visited Jan. 17, 2021); U.S. DeP'T of LAB., Model COBRA Continuation Coverage General Notice Instructions (2020) ("The Department considers use of the model general notice to be good faith compliance with the general notice content requirements of COBRA."). 
needs of plan participants with varying literacy abilities. ${ }^{132}$ And as will be discussed in Part II(B), plan administrators are not tailoring their SPDs to their plan participants, who might not be able to understand their SPDs' complex terminology without aid. ${ }^{133}$

\section{B. SPDs Today}

It is not a new idea to say that SPDs are complex. A 2006 study found that the average plan participant likely could not understand the information presented in their SPD. ${ }^{134}$ This study confirmed past research showing that participants could not understand their SPDs, and that, even when respondents thought they understood, "subsequent comments often revealed "how limited their understanding actually was.'"135 In part, this is likely because plan administrators often write SPDs to avoid legal liability and, therefore, produce SPDs that are written at advanced literacy levels that many Americans cannot understand. ${ }^{136}$

Additionally, while SPDs contain important information, much of that information is relevant only in specific situations. ${ }^{137}$ As a result, SPDs become encyclopedias rather than documents that should be read from cover to cover. ${ }^{138}$ In fact, most people never read their entire SPD. ${ }^{139}$ Yet some SPDs function poorly even as reference tools because

132. See supra note 102 and accompanying text.

133. See supra notes 101-03 and accompanying text.

134. Medill et al., supra note 26 , at 8 .

135. Alison McMorran Sulentic, Secrets, Lies Es ERISA: The Social Ethics of Misrepresentation and Omissions in Summary Plan Descriptions, $40 \mathrm{~J}$. Marshall L. Rev. 731, 742-43 (2007) (quoting James J. Bason \& Mary Ann Mauney, National Association of Insurance Commissioners Insurance Disclosure Focus Group Study 3-4 (Mar. 2005) (on file with authors)).

136. ERISA Advisory Council, Advisory Council Report on Health Care Literacy, U.S. DEP'T OF LAB., https://www.dol.gov/agencies/ebsa/ about-ebsa/about-us/erisa-advisory-council/2010-health-care-literacy [https://perma.cc/S8UF-3UBB] (last visited Jan. 6, 2021) ("[T]he testimony provided to the Council indicated that the SPDs are generally written at a level well above the literacy level of more than 40 percent of adults. Additional testimony noted that SPDs have become increasingly complex and legalistic in their descriptions in order to mitigate legal risks.").

137. Cf., e.g., Weaver Bros. Ins. Assocs. v. Braunstein, No. 11-5407, 2013 WL 1195529, at *10 (E.D. Pa. Mar. 25, 2013) (explaining that life-insurance conversion rights - which allow a participant terminating her employersponsored life insurance to convert that coverage into an individual policy - are important when a participant is terminating her employment due to a potentially fatal illness).

138. See id. at $* 9-10$.

139. Please Pass the Matches: The Unfortunate Truth about Your SPDs, FindLEY, https://findley.com/2017/03/summary-plan-descriptions/ [https://perma.cc/ 3GHC-EKLA] (last visited Dec. 22, 2021). 
they are a conglomeration of documents in various formats and styles wrapped together with an aptly named wrap document to form one plan. ${ }^{140}$ And as noted earlier, the National Assessment found that most Americans likely could not sort through multiple legal documents to determine which apply in any given health-care situation. ${ }^{141}$ Additionally, the compiled documents are likely to be standardized certificates or summaries, rather than documents that use customized format and language for a plan's participants. ${ }^{142}$ And even when SPDs are written for a plan, the drafter will often work with a standardized form that focuses on legal compliance rather than readability. ${ }^{143}$

Plan amendments can also add to SPD clutter. SPDs need to be redistributed to participants only once every five years. ${ }^{144}$ In the meantime, plan administrators can update SPDs using summaries of material modifications - called SMMs. ${ }^{145}$ To understand their benefits, participants must review both the SPD and its SMMs, but these SMMs might all be compiled in one section of the SPD — or even separate from the SPD. ${ }^{146}$ So a participant may not even realize an SMM applies when reviewing an SPD section. Additionally, SMMs can be delivered to participants up to sixty days after any material reduction in benefits, so participants may not have access to an SMM even as benefits are

140. What Is the Difference Between a Plan Document and a Summary Plan Description?, supra note 85 ("The insurance carriers typically provide employers with a master contract, certificate of coverage or summary of benefits, and employers may mistakenly assume this meets the ERISA requirement. These insurance-provided documents contain some but not all of the content required under ERISA. Therefore, in practice, 'wrap' documents are combined with the insurance-provided documents to meet the ERISA requirements."). Plan administrators wrap the documents for administrative ease: if all the documents are wrapped together in one plan, then the documents are legally treated as a single plan, even if they cover multiple benefits. Peter Wand, That's a Wrap, SHRM (Jan. 1, 2013), https://www.shrm.org/hr-today/news/hr-magazine/pages/0113-wrapdocuments.aspx [https://perma.cc/LWJ4-BKCC]. For an example wrap document, see Roger Williams Univ., Wraparound Summary Plan DESCRIPTION (SPD) (2014), https://www.rwu.edu/sites/default/files/ downloads/hr/medical-dental-other-insurance-summary.pdf [https:// perma.cc/3FVZ-348B].

141. See supra notes 101-03 and accompanying text.

142. See What Is the Difference Between a Plan Document and a Summary Plan Description?, supra note 85 ("The insurance carriers typically provide employers with a master contract, certificate of coverage or summary of benefits ....").

143. See Sosnin, supra note 25 .

144. ERISA $\S 104(\mathrm{~b})(1), 29$ U.S.C. $\S 1024(\mathrm{~b})(1)$. If no amendments have been made to a plan, then the plan administrator needs to redistribute the SPD only once every ten years. $I d$.

145. See generally 29 C.F.R. § 2520.104b-3 (2020).

146. See, e.g., WALmart, InC., supra note 19, at 296-337. 
changing. ${ }^{147}$ Add to all this information the fact that some SPDs are hundreds of pages long, ${ }^{148}$ and the studies that found SPDs difficult to understand appear even less surprising.

Another reason that SPDs are complex is that they are sometimes overly comprehensive. The Supreme Court, in the landmark case CIGNA Corp. v. Amara ${ }^{149}$ held that only a plan document could constitute a plan's terms. ${ }^{150}$ Yet subsequent courts have held that an SPD may itself be the plan document-making the SPD the plan's terms - if no other plan document exists. ${ }^{151}$ But Congress specifically created the SPD as a tool to help employees understand the terms of complex, comprehensive plan documents. ${ }^{152}$ So the question arises: how

147. 29 C.F.R. $§ 2520.104 b-3(d)$ (2020). SBCs partly address the problem because the ACA requires administrators to deliver updated SBCs at least 60 days before any material modification of benefits. ACA, Pub. L. No. 111-148, sec. 1001, § 2715(d)(4) (codified as amended at 42 U.S.C. $\S 300 \mathrm{gg}-15(\mathrm{~d})(4))$. But SBCs are not necessarily binding on plan terms, see 42 U.S.C. $\S 300 \mathrm{gg}-15(\mathrm{~b})(3)(\mathrm{H})$, and they are required only for medical plans, $i d$. $\S 300 \mathrm{gg}-15(\mathrm{a})$. Therefore, they have a limited impact on the problem of communicating plan changes.

148. See, e.g., Walmart, Inc., supra note 19; Duke University \& Health SYSTEM, 2019 Duke BenEFITS (2019), https://forms.hr.duke.edu/media/ benefits/Benefits\%20Summary\%20Plan\%20Descriptions\%202019.pdf [https://perma.cc/2SNX-8Q6A].

149. 563 U.S. 421 (2011).

150. Id. at 437-38.

151. E.g., MBI Energy Servs. v. Hoch, 929 F.3d 506, 511 (8th Cir. 2019); Mull v. Motion Picture Indus. Health Plan, 865 F.3d 1207, 1210 (9th Cir. 2017) ("In summary, neither the Trust Agreement nor the SPD meets ERISA's requirements for constituting a plan. But by clear design reflected in provisions of both documents, the two documents together constitute a plan."); Frazier v. Life Ins. Co. of N. Am., 725 F.3d 560, 563, 566-67 (6th Cir. 2013) (concluding that a long-term-disability carrier certificate could be the plan document). The circuit courts often rest their reasoning on either the fact that Amara "rest[ed] in important part upon the circumstances present' in that case (namely that there was both a plan document and a summary plan description) . . .," Hoch, 929 F.3d at 511 (quoting Amara, 563 U.S. at 425), or the bottom-line truth that a document must make up the plan terms, and in the absence of a separate plan document, the SPD is the most complete statement of plan terms, see Bd. of Trs. v. Moore, 800 F.3d 214, 220 (6th Cir. 2015) (citing Bd. of Trs. of the Nat'l Elevator Indus. Health Benefit Plan v. Montanile, 593 Fed. App'x. 903, 910 (11th Cir. 2014)). Despite these cases, the Supreme Court in Amara said that "[e]ven if the District Court had viewed the summaries as plan 'terms'... we cannot agree that the terms of statutorily required plan summaries (or summaries of plan modifications) necessarily may be enforced (under [ERISA] § 502(a)(1)(B)) as the terms of the plan itself." 563 U.S. at 437 . This would seem to imply that the Court would have reached the same result even if the SPD were the plan document, which would then conflict with circuit-court practice.

152. See supra notes 70-74 and accompanying text. 
are plan administrators accomplishing ERISA's goals within one document?

It could be that health and welfare benefits no longer require a separate plan document and summary either 1 ) because they are now simple enough to explain in one document, or 2) because administrators have found a manageable way to explain benefits comprehensively. But employer-provided health benefits continue to become more complex, ${ }^{153}$ and even modern SPDs are often difficult to understand. ${ }^{154}$ So plan administrators are likely not accomplishing ERISA's goals and are instead sacrificing readability by producing only one document.

This assertion is further confirmed by the fact that plan administrators often draft SPDs with objectively unambiguous and technical language to avoid liability in court rather than to communicate benefits effectively to plan participants. ${ }^{155}$ Though unambiguous communication might seem like the best way to empower participants, language must be tailored to those participants for the disclosure to be effective. ${ }^{156}$ Additionally, though full disclosure remains the practice in employee benefits ${ }^{157}$ attorneys in other legal fields are finding that complete disclosure presents so much information to readers that the disclosure is unhelpful. ${ }^{158}$ And jury instructions have

153. Advisory Council, supra note 25 .

154. See supra notes 134-36.

155. See Advisory Council, supra note 136; Amanda N. Eastman, ERISA Finally Makes Sense by Making Employees Whole: Can Make-Whole Remedies for American Workers Spur Transparency from Employee Benefit Plans?, 22 KAN. J.L. \& PuB. PoL'y 412, 430 (2013) ("During an American Law Institute Continuing Legal Education conference, a benefits attorney urged his fellow law practitioners to be mindful of the teachings of Amara when communicating with employees about benefits and administering benefit plans. He stressed the importance of clear, accurate, and unambiguous communications to employees with 'all of the plaintiff's bar salivating' to pounce on any misstatements that could potentially entitle participants to equitable relief." (emphasis added) (footnotes omitted)).

156. See supra notes 100-02, 116-19 and accompanying text.

157. See supra notes 74-79 and accompanying text.

158. Daniel Susser, Notice After Notice-and-Consent: Why Privacy Disclosures Are Valuable Even If Consent Frameworks Aren't, 9 J. InFo. POL'y 37, 44 (2019) (discussing the "dense legalese" of privacy notices); Stephanie E. Dreyer \& Peter G. Weinstock, Less Is More: Changing the Regulator's Role to Prevent Excess in Consumer Disclosure, 123 BAnking L.J. 99, 101 (2006) (noting that financial disclosures are usually written so that only "the financially sophisticated" can understand them, and therefore, "the prototypical 'naive consumer' . . . may not receive any meaningful benefit ...."). 
been routinely criticized for using technically accurate but overly complex language. ${ }^{159}$

SPDs suffer from the same problems: they contain too much information, ${ }^{160}$ and plan administrators write them for an advanced audience. ${ }^{161}$ Sadly, it appears that these problems are the same that preERISA benefit communications had. ${ }^{162}$ Fortunately, employers are aware of the benefit-communication difficulties. ${ }^{163}$ But unfortunately, as a result of these difficulties, many SPDs fail to accomplish their purpose of effectively communicating benefits to plan participants.

\section{SPDS IN COURT}

As discussed briefly in Part I, ERISA includes enforcement mechanisms. ${ }^{164}$ In addition to the monetary and criminal penalties for failing to distribute SPDs, ERISA allows a plan participant to sue based on a plan's terms. ${ }^{165}$ Despite foreclosing suits that use the SPD as the plan's terms when there is a separate plan document, ${ }^{166}$ the Supreme Court in Amara left open the possibility that a participant could sue

159. See, e.g., Laurence J. Severance \& Elizabeth F. Loftus, Improving the Ability of Jurors to Comprehend and Apply Criminal Jury Instructions, 17 LAW \& Soc'Y REv. 153, 154-55 (1982).

160. See supra notes $140-52$ and accompanying text.

161. See supra notes $134-36$ and accompanying text.

162. Compare Medill et al., supra note 26, at 8, and Advisory Council, supra note 136 ("Additional testimony noted that SPDs have become increasingly complex and legalistic in their descriptions in order to mitigate legal risks."), with H.R. Rep. No. 93-533, at 8 (1973), as reprinted in 1974 U.S.C.C.A.N. 4639, 4646 ("Subcommittee findings were abundant in establishing that an average plan participant, even where he has been furnished an explanation of his plan provisions, often cannot comprehend them because of the technicalities and complexities of the language used.").

163. The Guardian Life Insurance Company of America, The Guardian Workplace Benefits Study: Fourth Annual 7 (2016) ("Roughly 1 in 4 companies cite employee benefit communication/ education and installing new benefits or changing carriers/TPAs as the most difficult [benefits] aspects to manage."); ADP, Fact Sheet - ADP HR/Benefits Pulse Survey (\#652) 1 (Aug. 26, 2011), https://www.adp.com//media/pdf/pulse-survey-employee-benefit-tools-fact-sheet-12-13-2011.pdf [https://perma.cc/5SJV-ZE2M] ("Eighty percent of HR decision makers believe it's important for employees to fully understand their benefit options, yet they estimate only about $60 \%$ of their own employees do ....").

164. See supra notes $82-84$ and accompanying text.

165. ERISA § 502(a)(1)(B), 29 U.S.C. § 1132(a)(1)(B).

166. See supra notes $150-51$ and accompanying text. 
"to obtain other appropriate equitable relief." ${ }^{167}$ However, the Court did not address how to interpret SPDs when they cannot create a plan's terms or override a conflicting plan document.

But other courts have evaluated whether an SPD is lawfully written, looking to ERISA's requirement that SPDs be written for the average plan participant. ${ }^{168}$ In addition to evaluating the words used, a court might also analyze the SPD's format. ${ }^{169}$ If the SPD violates ERISA's requirements, then "a court may estop a plan administrator from denying coverage for terms not included in the SPD."

\section{A. "[C]alculated to be understood by the average plan participant"?}

When evaluating whether an SPD satisfies ERISA's requirement that it "be written in a manner calculated to be understood by the average plan participant," ${ }^{171}$ courts apply an objective standard. ${ }^{172}$ For instance, courts use standards such as:

- "SPDs [should] be interpreted from the perspective of a layperson . . ."; ${ }^{173}$

167. CIGNA Corp. v. Amara, 563 U.S. 421, 438-42 (2011) (emphasis omitted) (discussing ERISA § 502(a)(3)).

168. E.g., Harris Methodist Fort Worth v. Sales Support Servs. Inc. Emp. Health Care Plan, 426 F.3d 330, 334, 336 (5th Cir. 2005).

169. Chisholm v. Plan Adm'r of Joint Indus. Bd. of Elec. Indus. Benefit Funds, No. CV-03-1968, 2004 WL 3267292, at *3-4 (E.D.N.Y. Oct. 19, 2004) (evaluating the distance between relevant plan provisions and the font of the provisions, rather than the complexity of the words).

170. Hopkins v. Prudential Ins. Co. of Am., 432 F. Supp. 2d 745, 758-59 (N.D. Ill. 2006) (quoting Mers v. Marriott Int'l Group Accidental Death \& Dismemberment Plan, 144 F.3d 1014, 1022 (7th Cir. 1998)) ("A two-part framework is used to analyze alleged conflicts between a plan and an SPD. First, before examining any alleged conflicts between the two, the Court must determine whether the SPD satisfies the disclosure requirements set forth of 29 U.S.C. $\S 1022$. In making this determination, the Court need not consider whether the terms of the plan clarify or contradict the terms of the SPD. If the SPD fails to satisfy $\S 1022$, 'a court may estop a plan administrator from denying coverage for terms not included in the SPD.' If, however, the SPD does satisfy $\S 1022$, then the court proceeds to the second prong, which entails looking at both the SPD and the plan to determine whether there is a direct conflict between the two. If there is a direct conflict, the claimant can rely on the terms in the SPD to estop the plan administrator from denying coverage based on the plan." (citations omitted) (citing Mers, 144 F.3d at 1022-24)).

171. ERISA § 102(a).

172. See, e.g., Wilson v. Southwestern Bell Telephone Co., 55 F.3d 399, 407 (8th Cir. 1995) (noting that ERISA's readability requirement "appears to be an objective standard rather than requiring an inquiry into the subjective perception of the individual participants").

173. Harris Methodist Fort Worth, 426 F.3d at 336. 
- SPDs should use "familiar language and format" while avoiding "confusing or technical terms"; 174

- SPD words should be given their "common and ordinary meaning as a reasonable person in the position of the [plan] participant, not the actual participant, would have understood the words"; 175 and

- SPDs can be interpreted using the dictionary. ${ }^{176}$

But ERISA's language indicates that SPDs should be tailored so that a plan's participants can understand them, rather than tailored to an objective standard. When analyzing ERISA's language, as with other statutes, courts begin with the statute's plain language, ${ }^{177}$ but must also "take care not to interpret the language in a vacuum; instead, [the court] must look to the 'structure, history, and purpose' of the statutory scheme." 178

Both ERISA's text and purpose indicate that SPDs should be tailored to a plan's participants, rather than tailored for a theoretically objective plan participant or a reasonable person. When taken out of context, ERISA's readability requirement appears unclear because it references "the average plan participant" without indicating whether average refers to the average plan participant nationally, locally, or otherwise. ${ }^{179}$ But the other uses of the word plan in the same statutory section refer to a specific plan rather than all plans: "[a] summary plan description of any employee benefit plan shall be furnished to participants and beneficiaries;" and "[t]he summary plan description ... shall be sufficiently accurate and comprehensive to reasonably apprise such participants and beneficiaries of their rights and obligations under the plan." 180 This implies that the phrase average plan participant is referring to the average participant in a specific plan. Additionally, Congress used the words "average plan participant," not the words average person or reasonable person. ${ }^{181}$

Furthermore, the DOL regulations similarly interpret ERISA: "the plan administrator shall exercise considered judgment and discretion by

174. Wilson, 55 F.3d at 407.

175. Antolik v. Saks Inc., 391 F. Supp. 2d 771, 780 (S.D. Iowa 2005) (alteration in original) (citing Hughes v. 3M Retiree Med. Plan, 281 F.3d 786, 790 (8th Cir. 2002)), rev'd on other grounds, 463 F.3d 796 (8th Cir. 2006).

176. Mattias v. Computer Scis. Corp., 34 F. Supp. 2d 120, 127 (D.R.I. 1999) (using the dictionary to interpret "partial disability" within the SPD when the SPD conflicted with the plan document).

177. Hale v. Johnson, 845 F.3d 224, 227 (6th Cir. 2016) (quoting United States v. Ron Pair Enters., Inc., 489 U.S. 235, 241 (1989)).

178. Id. (quoting Abramski v. United States, 573 U.S. 169, 179 (2014)).

179. ERISA § 102(a)(1), 29 U.S.C. § 1022(a).

180. Id. (emphasis added).

181. See 29 U.S.C. $\S 1022(a)$. 
taking into account such factors as the level of comprehension and education of typical participants in the plan and the complexity of the terms of the plan." 182 Because Congress gave the DOL power to administer the SPD provisions of ERISA, ${ }^{183}$ even if a court did find that ERISA's language is ambiguous, the court should then defer to the DOL's interpretation. ${ }^{184}$

ERISA's purpose also points toward a tailored SPD. Recall that Congress intended to empower plan participants through disclosure so that participants could reliably utilize benefits and hold plan administrators to plan terms. ${ }^{185}$ Courts and commentators have acknowledged this statutory goal. ${ }^{186}$ Yet, if an SPD is written so that it is objectively understandable and not ambiguous, it does not necessarily follow that participants understand the text. ${ }^{187}$ While courts do not indicate who their average "layperson" is, they state that SPDs should be written in plain language, giving words their ordinary meaning. ${ }^{188}$

182. 29 C.F.R. $\S 2520.102-2(\mathrm{a})$ (2020) (emphasis added). The DOL drafted the regulations for SPDs. Summary Plan Description Requirements; Final and Interim Regulations, 42 Fed. Reg. 37178, 37180 (July 19, 1977) (codified as amended at 29 C.F.R. pt. 2520).

183. See New York v. U.S. Dep't of Lab., 363 F. Supp. 3d 109, 128 (D.D.C. 2019) (first citing 29 U.S.C. § 1135; and then citing Black \& Decker Disability Plan v. Nord, 538 U.S. 822, 831 (2003)).

184. Chevron, U.S.A., Inc. v. Nat. Res. Def. Council, Inc., 467 U.S. 837, 844 (1984).

185. See supra notes $67-73$ and accompanying text.

186. See, e.g., Hansen v. Cont'l Ins. Co., 940 F.2d 971, 981-82 (5th Cir. 1991) ("Of course, if a participant has to read and understand the policy in order to make use of the summary, then the summary is of no use at all."), abrogated by CIGNA Corp. v. Amara, 563 U.S. 421 (2011); WiEDENBECK, supra note 33, at 16 .

187. See supra notes $134-36$ and accompanying text. Here is a particularly amusing (or maybe baffling) example of a court conflating objectively unambiguous language with a participant's ability to understand it. While comparing an individualized enrollment worksheet that contained errors to an SMM (the "booklet"), the court said:

Nor were the errors the least bit difficult to decipher: What the worksheet seemed to provide - basic life insurance of $\$ 10,000$ plus three times the employee's base salary and supplemental insurance of $175 \%$ of base salary - the booklet specifically precluded by eliminating the $\$ 10,000$ benefit, by offering basic insurance of just two times the employee's base salary and by permitting supplemental insurance only in $100 \%$ increments.

Crosby v. Rohm \& Haas Co., 480 F.3d 423, 431 (6th Cir. 2007). The court, based on its own objective reading of the documents, said that "[t]he terms of this plan ... were exceedingly clear," and therefore the plaintiff should not have relied on the incorrect "informal" worksheet. Id.

188. See supra notes $173-76$ and accompanying text. 
Given that so few plan participants nationally have the ability to synthesize information from benefit documents like SPDs - even if they can read the words ${ }^{189}$ - the objective standards used by courts fall short. Not only do they remove the tailoring requirement, but they also fail to adequately capture the intricacies of reading an SPD. A tailored SPD is needed so that plan participants can read their SPDs and synthesize helpful information from them.

Practical challenges could be raised against this Note's assertion that plan administrators should tailor SPDs. For instance, regulatorycompliance complexity and costliness are frequently cited concerns when regulators want to place additional responsibilities on plans. ${ }^{190}$ However, the American insurance and healthcare systems are complex and costly regardless of what plan administrators do, ${ }^{191}$ and failing to hold plan administrators to a high standard of communication inevitably means that plan participants will bear the brunt of their poor health literacy, as they are doing now. ${ }^{192}$ In other words, regulating employers and plans is not an attempt to increase the overall burden of the American healthcare system; rather, it is an attempt to place the preexisting burden - in this case, the burden of low health literacy - on the parties that are best able to bear it and are required to bear it by law. Plan administrators are in a better position than participants to bridge the gap between plan terms and participant health literacy: as the SPD drafters, plan administrators can more efficiently tailor benefit communications than participants can sort through and understand

189. See supra notes 101-03 and accompanying text.

190. E.g., Phil Albinus, Compliance, Cost Containment Overwhelm Benefit Managers, Emp. Benefit News (Feb. 6, 2017, 10:21 PM), https://www. benefitnews.com/news/compliance-cost-containment-overwhelm-benefitmanagers [https://perma.cc/UM69-3KXH] ("A majority of U.S. employers feel overwhelmed in the race to control costs, manage benefit programs and meet compliance regulations ...." (citing ThE GuARDiAn, supra note 163)).

191. Cheryl A. Camillo, The US Healthcare System: Complex and Unequal, 3 Glob. Soc. Welfare: Rsch, Pol'y, and Prac. 1, 1 (2016) ("[T]he US health care delivery system is uniquely complex, costly, and unequal."); see also articles cited supra note 122.

192. See supra notes 111-12. 
complex SPDs. ${ }^{193}$ Accordingly, ERISA gives plan administrators the responsibility to clearly communicate benefits. ${ }^{194}$

Some plans might warrant special consideration, such as smallemployer plans, which may not have larger plans' resources, but as will be discussed in Part IV, the DOL has broad authority to craft SPD regulations and could, therefore, create special regulations as needed to address a variety of situations.

\section{B. Reliance Issues}

In addition to harm from how courts evaluate SPDs, plan participants cannot always rely on employer-provided communication as legally binding. As the Supreme Court noted in Amara, allowing participants to rely on SPDs could cause SPDs to become more technical over time, as plans seek to avoid liability ${ }^{195}$ - and that is exactly what has happened. ${ }^{196}$ In contrast, prior to Amara, the Fifth Circuit reasoned that SPDs would be essentially useless if participants could not rely on them because participants would need to digest their plan document to find out which terms truly bound them. ${ }^{197}$ As one commentator put it, letting the plan terms consistently override the SPD "would utterly defeat the informational objectives of [ERISA]."198 Though the Supreme Court specifically allowed participants to obtain equitable relief for SPD problems, it remains to be seen how most courts will grant relief to participants going forward. ${ }^{199}$

Another problem is how some courts handle plan communications other than the SPD. Participants who rely on inaccurate information

193. Cf. Colleen McCullough, Unconscionability as a Coherent Legal Concept, 164 U. PA. L. REV. 779, 782 (2016) ("Most courts do not find contracts of adhesion to be unconscionable per se, though they typically consider the lack of bargaining power and inability to choose, negotiate, or understand terms as indications of procedural unconscionability."). Plan documents, and SPDs by extension, are essentially adhesion contracts: the plan sponsor and plan administrator together have a substantial majority of the bargaining power because they choose the plan's terms - i.e. what benefits to cover and how to cover them - and then choose the language of the plan document and the SPD. See supra Part I(B), Part II(B).

194. See supra notes $81-87$ and accompanying text.

195. CIGNA Corp. v. Amara, 563 U.S. 421, 437-38 (2011).

196. Advisory Council, supra note 25.

197. Hansen v. Cont'l Ins. Co., 940 F.2d 971, 981-82 (5th Cir. 1991), abrogated by Amara, 563 U.S. 421 (2011).

198. WiEDENBECK, supra note 33 , at 82.

199. See 3 Lee T. Polk, ERISA Practice And Litigation $§ 12: 38$, Westlaw (database updated Dec. 2020) ("[A] closer look at Amara and its reception in the lower courts reveals that its thrust is far less broad than might initially be thought. The lower courts are now beginning to address the boundaries that Amara set."). 
in non-SPD documents may be left without a remedy in court, even if those supplemental documents are individualized. In Crosby v. Rohm E Haas Co., ${ }^{200}$ the Sixth Circuit held that a plan participant could not rely on a personalized worksheet that included benefit estimates because "the worksheet amounted to no more than an informal communication" and, therefore, "could not amend the terms of the plan." ${ }^{201}$ The court also held that the participant's equitable estoppel claim failed because the incorrect communication did not contain an element of fraud. ${ }^{202}$ As a result, the Crosby court implied that participants should rely on generic forms over individualized ones. ${ }^{203}$

Because participants do not know which parts of a non-SPD communication might conflict with the SPD, they would need to read the SPD from cover to cover or at least compare the supplemental document against every relevant SPD provision. ${ }^{204}$ Though not quite the same task as sifting through multiple legal documents, the National Assessment's results imply that the average employee might have trouble with this comparison. ${ }^{205}$ And it is striking that a court would expect participants to rely more on their own benefit calculations from their SPD than on an individualized form provided by the plan administrator - especially given that the National Assessment on health

200. 480 F.3d 423 (6th Cir. 2007).

201. Id. at 429. The worksheet in this case contained a disclaimer that it should be "review $[$ ed] . . . for accuracy." Id. (alteration in original). For a discussion of why such disclaimers in SPDs conflict with ERISA's disclosure goals, see generally James F. Stratman, Contract Disclaimers in ERISA Summary Plan Documents: A Deceptive Practice?, 10 Indus. REL. L.J. 350 (1988).

202. Crosby, 480 F.3d at 431. The Sixth Circuit has found fraud where a plan's representatives were the only people "in a position to know" whether a supplemental document was accurate and repeatedly told a participant that the document was correct. Deschamps v. Bridgestone Americas, Inc. Salaried Emps. Ret. Plan, 840 F.3d 267, 274-75 (6th Cir. 2016) (distinguishing the facts in Crosby from the facts in Paul v. Detroit Edison Co. \& Mich. Consol. Gas Co. Pension Plan, 642 Fed. Appx. 588 (6th Cir. 2016)). Therefore, consistent with Crosby, in situations where participants can find errors on their own-again, likely according to an objective standard of readability - the court might not find fraud. Crosby, 480 F.3d at 431 (noting that errors were not "the least bit difficult to decipher").

203. Crosby, 480 F.3d at 429.

204. In fact, the court in Crosby implied as much: "[t] he accompanying booklet advised [the participant] to check the worksheet for 'errors or omissions' and to 'speak with a representative' should he find any. Far from trying to deceive...these instructions were designed to prevent [plan participants] from relying on the worksheet alone." Id. at 431 (citation omitted).

205. See supra notes 101-03 and accompanying text. 
literacy results implied that most adults could not calculate the costs for benefits. ${ }^{206}$

The law could be changed to allow employees and participants to rely on these non-SPD benefit communications, but that rule would add another layer to a compliance system that is already multilayered with plan documents, SPDs, SMMs, and SBCs. ${ }^{207}$ But as this Note will discuss in Part IV, these tailored benefit summaries could replace the SPD, which would fix the problems of tailoring and reliance, and reduce the total number of documents that participants must review.

\section{FIXING ThE SPD FAILURE}

In 2005, the Advisory Council of Employee Welfare and Pension Benefit Plans ${ }^{208}$ issued a report to the DOL on health-and-welfarebenefit-plan communications. ${ }^{209}$ The Council noted that "[t]he consensus of the plan administrator advocates was that the DOL's requirement that SPDs be written in a manner calculated to be understood by the average participant has become almost impossible to attain." ${ }^{210}$ The Council recommended only vague fixes, including that the DOL "[p]rovide regulatory or advisory guidance" to aid plan administrators and find ways to better enforce ERISA's SPD readability requirement. ${ }^{211}$

The Advisory Council followed up the 2005 report with a report in 2010 regarding health-care literacy. ${ }^{212}$ The Council made several recommendations aimed at standardizing health-care language in employer plans. ${ }^{213}$

Two of the recommendations dealt with SPDs. The first recommendation was that "[t]he DOL should consider whether it would be appropriate for SPDs to have a separate section containing the technical and legally required information not directly related to the health benefits offered under the plan." ${ }^{214}$ But this separation already

206. See supra notes 101-03 and accompanying text; see also supra note 117 and accompanying text.

207. See supra notes 69-74, 129, 145-46 and accompanying text.

208. ERISA created the Advisory Council "to advise the Secretary [of Labor] with respect to the carrying out of his functions under this Act and to submit to the Secretary recommendations with respect thereto." ERISA, Pub. L. No. 93-406, § 512(b), 88 Stat. at 896 (codified as amended at 29 U.S.C. $\S 1142(\mathrm{~b}))$.

209. Advisory Council, supra note 25.

210. Id.

211. $I d$.

212. Advisory Council, supra note 136.

213. Id.

214. Id. 
occurs for plans that utilize wrap documents, since the wrap document itself is the legal language that creates the plan. ${ }^{215}$ And even full SPDs tend to separate legal notices into their own sections, often near the document's end. ${ }^{216}$ So the DOL may not need to take any further action on this recommendation.

The Advisory Council made a second recommendation, though: that the SPD include a shortened benefit summary providing "basic, necessary information upfront with clear direction provided so participants and beneficiaries know where to obtain additional specific information." 217 This recommendation comes closer than the first to solving the SPD failure because it attempts to simplify benefit communications. Notably though, it would not mandate tailored SPDs, as required by ERISA, ${ }^{218}$ nor would it allow participants to rely on the shortened summary. But it would further burden plan administrators by adding an additional document to the compliance list.

Despite the Advisory Council's recommendations, SPD regulations have not been updated in ways that substantially impact their readability, ${ }^{219}$ other than some updates to electronic disclosure requirements for retirement-plan SPDs. ${ }^{220}$ Given that most plan participants likely have poor health literacy ${ }^{221}$ and that SPDs are not helping them understand their benefits, ${ }^{222}$ the current regulations need to be modified to better meet ERISA's goals.

215. See supra note 140.

216. See, e.g., WAlmart, Inc., supra note 19, at 280-93.

217. Advisory Council, supra note 136.

218. See supra notes $177-89$ and accompanying text.

219. The DOL promulgated other regulations after the Advisory Council's report, but they did not impact health and welfare SPDs. See Electronic Filing of Notices for Apprenticeship and Training Plans and Statements for Pension Plans for Certain Select Employees, 84 Fed. Reg. 27952. (June 17, 2019) (codified at 29 C.F.R. pt. 2520) (updating filing requirements for certain types of non-health-and-welfare employee-benefit plans); Annual Funding Notice for Defined Benefit Plans, 80 Fed. Reg. 5626 (Feb. 2, 2015) (codified at 29 C.F.R. pt. 2520) (implementing ERISA regulations for pension-plan annual funding notices); Filings Required of Multiple Employer Welfare Arrangements and Certain Other Related Entities, 78 Fed. Reg. 13781 (Mar. 1, 2013) (codified at 29 C.F.R. pt. 2520) (updating required MEWA filings); Multiemployer Pension Plan Information Made Available on Request, 75 Fed. Reg. 9334 (Mar. 2, 2010) (codified at 29 C.F.R. pt. 2520) (regarding multiemployer-pension-plan actuarial and financial disclosures).

220. Default Electronic Disclosure by Employee Pension Benefit Plans Under ERISA, 85 Fed. Reg. 31884, 31922-24 (July 27, 2020) (codified at 29 C.F.R. pts. 2520, 2560) (making it easier to satisfy SPD delivery requirements by publishing retirement SPDs online).

221. See supra Part II(A).

222. See supra Part II(B). 


\section{A. Working with Current Employer Practices}

Plan sponsors and plan administrators are aware of the difficulties of communicating health benefits. ${ }^{223}$ And as the drafters of plan documents and SPDs, they are also aware of the costs involved in SPD creation and distribution. ${ }^{224}$ Plan sponsors offer benefits to attract and retain employees, ${ }^{225}$ but employees must understand the employersponsored benefits before they will view them as employment perks. ${ }^{226}$ Thankfully, employers know that SPDs are not working, ${ }^{227}$ so they are turning to other benefit disclosures, such as town hall meetings, videos, benefit updates, and open-enrollment materials. ${ }^{228}$ And a new focus on online materials matches a current plan-participant practice: participants are already turning to online sources in lieu of the SPD to learn about their benefits. ${ }^{229}$ But even clearly labeled, short paper documents could mitigate the problem that participants have sifting through complex SPDs. ${ }^{230}$ Importantly, though, plan administrators

223. See sources cited supra note 163.

224. See Advisory Council, supra note 25 ("The administrative cost of developing, producing and distributing [SPD] hard copies has become burdensome"); cf. Sosnin, supra note 25 (noting that drafting an effective SPD requires collaboration between "[b]enefits people," "a communication specialist familiar with ERISA," and "an experienced attorney").

225. See Stephen Miller, Employers Boost Benefits to Win and Keep Top Talent, SHRM (June 25, 2019), https://www.shrm.org/resourcesandtools/hr-topics/ benefits/pages/employers-boost-benefits-to-win-and-keep-talent.aspx [https://perma.cc/RQL4-XZKC].

226. See WiEdEnBECK, supra note 33, at 107 ("The sponsor, however, cannot afford to have workers undervalue the benefits provided, and so the employer will resort to other methods of publicizing the advantages of the plan.").

227. See supra note 210 and accompanying text.

228. Advisory Council, supra note 25; see Communication and Education Strategy, AM. Fidelity, https://americanfidelity.com/strategy/communication-andeducation/ [https://perma.cc/SAD6-EP47] (last visited Jan. 4, 2021) (advertising the following as communication options: videos, "benefits website[s] with enrollment preparation information," emails, "posters, flyers, postcards, and brochures to help ensure [that] employees understand their benefits and know when it's time to enroll").

229. DirectPATH, supra note 10, at 2 (" $40 \%$ of respondents report having taught themselves about health insurance terms and processes (e.g., how to enroll in coverage, how to find an in-network provider, how to anticipate treatment costs) using online resources or other materials."); accord KUTNER ET AL., supra note 3, at 45 (indicating that many survey respondents received information from online sources, but not separating results by insurance type).

230. The National Assessment found that only individuals with proficient literacy could "[f]ind the information required to define a medical term by searching through a complex document" and "evaluate information to 
need flexibility to design benefit communications that are tailored to their participants, as required by ERISA. ${ }^{231}$

The DOL has broad power to regulate employee-benefit disclosures, ${ }^{232}$ including the power to "prescribe the format and content of [SPDs]." ${ }^{233}$ The DOL can even simplify disclosure requirements for welfare plans. ${ }^{234}$ It could, therefore, require simplified documents in addition to SPDs, but that would leave participants with the problem of having multiple documents defining the same benefits. ${ }^{235}$

Instead, the DOL should promulgate new regulations that treat separate tailored benefit communications - both physical documents and online disclosures - as the SPD itself. The DOL should also allow plan administrators to use the ACA's required SBC as an SPD communication, further simplifying benefit communications. Additionally, the DOL should allow administrators to produce individualized benefit documents, which removes for participants the added step of determining eligibility and costs, hopefully further mitigating health-

determine which legal document is applicable to a specific health care situation." KUTNER ET AL., supra note 3, at 6. Since most plan participants appear to be less than proficiently literate, see supra notes 102-03, 116-19 and accompanying text, creating shorter documents that are less legalistic might help more participants understand their benefits. Additional research would be needed to determine whether any benefitdisclosure changes actually improve participant health literacy.

231. Advisory Council, supra note 25 ("Complexity of the terms of the plan necessitates the use of a variety of communication tools, in lieu of a single document (i.e., SPD), to explain benefit plans, not only at the time an employee becomes a participant, but also at the time of utilization . . . ."); see supra notes 185-93 and accompanying text. For a sample benefit guide, see Explain My Benefits, Employee Benefits Guide (2017), https://www.explainmybenefits.com/wpcontent/uploads/2017/01/Sampl e-Benefit-Guide-2.pdf [https://perma.cc/KR64-UPGD] (last visited Jan. 4, 2021). For an example of a complex benefits guide, see Harvard Hum. Res., EnRollment Guide: 2021 Benefits (2021), https://hr.harvard.edu/ files/humanresources/files/benefitsenrollmentguide_facultynonunionstaff .pdf [https://perma.cc/V5SL-YCCR]. For an example of PowerPoint slides that communicate important benefit information, see WiLliams, Open ENROLLMENT 2021 (2020), https://hr.williams.edu/files/2020/10/2021Open-Enrollment-Info-Session.pdf [https://perma.cc/JVA3-CAWG]. For an example of an interactive benefits website, see My Health, WALMART, https://one.walmart.com/content/usone/en_us/me/health.html [https:// perma.cc/54K3-GRGJ] (last visited Dec. 23, 2021).

232. 29 U.S.C. $\S 1135$ ("[T]he Secretary may prescribe such regulations as he finds necessary or appropriate to carry out the provisions of this subchapter.").

233. 29 U.S.C. $\S 1029(c)$.

234. 29 U.S.C. $\S 1024(\mathrm{a})(3)$.

235. See supra notes 140-48. 
literacy concerns raised by the National Assessment regarding calculating costs and searching through multiple documents. ${ }^{236}$

As long as all of the disparate documents are provided to plan participants within the time required by law, the disclosures would meet the statutory requirements, even if they were not all provided at once in a single encyclopedic document. ${ }^{237}$ Plan administrators would still need to communicate the information required by law ${ }^{238}$ but would have flexibility to communicate that information in various ways, tailored to each benefit and to participants' needs. ${ }^{239}$

These new regulations could also mitigate the problem of having an SPD with multiple attached SMMs modifying it. ${ }^{240}$ By having separate documents for different benefits or smaller benefits booklets, updating and redistributing shorter documents more frequently would be less burdensome than updating and redistributing an entire SPD, especially now that documents can be distributed electronically. ${ }^{241}$

Additionally, the new regulations would not put additional burdens on many plan sponsors and plan administrators, since they are already communicating benefits in this way. ${ }^{242}$ Keeping compliance requirements the same or even reducing them-since employers could scrap the complex and legalistic single-document SPD altogetherwould, therefore, address a significant concern of plan sponsors and administrators. ${ }^{243}$

But if the DOL increases flexibility in SPD preparation, it still must ensure that the new SPD documents are understandable so that administrators use that flexibility to tailor documents to participants rather than to save money.

236. See supra note 230 and accompanying text.

237. The SPD documents' contents would satisfy 29 U.S.C. $\S 1022(\mathrm{~b})$ when reviewed together.

238. 29 U.S.C. $\S 1022(\mathrm{~b})$.

239. Health literacy varies across plan participants. See supra notes 102-03 and accompanying text. It also varies based on gender, race, and wealth, and therefore, plan administrators may need flexibility to create a variety of summaries communicating the same information in different ways to accommodate various health literacy levels within the same plan. See supra note 102. But the law requires that plan administrators target SPDs to "the average plan participant." 29 U.S.C. § 1022(a). Unfortunately, that requirement may be inadequate, or even discriminatory, given the disparities found in the National Assessment.

240. See supra notes 144-46 and accompanying text.

241. 29 C.F.R. § 2520.104b-1(c) (2020).

242. See supra notes 225-29 and accompanying text.

243. Advisory Council, supra note 25 ("The general consensus was not to impose more burdens on plan sponsors than already required."). 


\section{B. Enforcing ERISA's Readability Requirement}

The Advisory Council recommended that the DOL "[e]nhance or create mechanisms to enforce the regulatory requirement that SPDs be understandable by the average plan participant." 244 When updating SPD requirements, the DOL will need to address 1) how plan administrators should draft SPDs to match participant literacy, and 2) which literacy level or levels administrators should target. To make those changes useful to participants who rely on improperly drafted SPDs, courts will then need to apply the updated requirements when interpreting SPDs.

\section{Using Literacy Tools to Draft Tailored SPDs}

As discussed in Part III(A), a plan's SPD should be tailored to that plan's participants. Courts have focused on whether "the average plan participant" can understand SPDs, ${ }^{245}$ but there is another phrase in the law: "written in a manner calculated to be understood by the average plan participant." 246 The law's language does not require that plan administrators write SPDs that are in fact understandable by plan participants, but rather that SPDs be "calculated to be understood by" plan participants. ${ }^{247}$

The distinction may seem semantic, but it helps inform how the DOL might better enforce ERISA's readability requirement: require plan administrators to provide proof that they took calculated steps to ensure that they wrote their SPD documents so that the average plan participant could understand them. ${ }^{248}$ For instance, plan administrators could survey participants regarding which benefits communications they prefer, assess participant literacy, or test benefit communications against literacy grades. ${ }^{249}$

Additionally, the new regulation might also encourage plan sponsors to work with industry organizations to make recommendations as to what types of benefit communications are most likely to be understood by a particular employee population. ${ }^{250}$ But plan administrators

244. Id.

245. See supra Part III(A).

246. 29 U.S.C. $\S 1022($ a) (emphasis added).

247. Id. (emphasis added).

248. The proof would be provided either if the DOL requests it or if the plan is sued in court under 29 U.S.C. $\S 1132(\mathrm{a})$.

249. See infra notes $253-61$ and accompanying text.

250. The Advisory Council called this "culturally appropriate communication[]." Advisory Council, supra note 136 ("The Council found particularly compelling one example of how an employer in the fashion industry had increased plan enrollment after making a plan communication resemble a fashion/lifestyle magazine. The DOL should encourage employers to pay particular attention to designing culturally appropriate communications."). 
would benefit from the DOL's guidance on how best to measure participant literacy and draft literacy-tailored SPDs in a way that would guard the administrator against liability in court when the administrator relies on those literacy metrics. ${ }^{251}$ As recommended by the Advisory Council, the DOL could work with the Department of Health and Human Services and other groups to create appropriate metrics. ${ }^{252}$

These literacy metrics would likely need to combine two assessments: 1) an assessment to determine the literacy level of employees, and 2) an assessment to determine whether SPD documents match employee literacy. Several literacy tests of both types exist, ${ }^{253}$ but the DOL would need to exercise its expertise to choose the best tools and to customize those tools for health-plan SPDs. And just as third-party administrators began drafting SPDs after ERISA, ${ }^{254}$ the demand for aid in drafting readable SPDs might encourage the creation of literacy-assessment professionals.

Plan administrators may complain about additional burdens but this Note's recommendations would remove the current SPD requirement by replacing it with documents and tools that plan administrators are already creating, which would help reduce that burden. ${ }^{255}$ Moreover, plan administrators are in the best position to bear the burden of creating a readable SPD. ${ }^{256}$ And the DOL could help by creating standardized forms to use with employees at different literacy levels. ${ }^{257}$ But as the Advisory Council noted, more research and brainstorming are needed to determine which literacy tools would be best, ${ }^{258}$ and that exploration is beyond the scope of this Note.

251. Id.

252. Id.

253. Several grading methods have already been established for documents, including "the Flesch Reading Ease Formula, the Flesch Grade Level Formula, and the Fog Index." Medill et al., supra note 26, at 5. For an overview of health literacy measures in the medical context, see Health Literacy Measurement Tools (Revised), AgEnCy FOR HeAlthCARE Rsch. \& QUALITY, https://www.ahrq.gov/health-literacy/research/tools/ index.html [https://perma.cc/TPH5-45V4] (Nov. 2019). These tools would need to be updated to measure SPD comprehension as opposed to medical-term comprehension.

254. See Sosnin, supra note 25.

255. See supra Part IV(A).

256. See supra notes 190-94 and accompanying text.

257. Though the DOL currently produces standardized documents for all plans, see supra note 131, these new standardized documents would be targeted at various literacy levels.

258. Advisory Council, supra note 136 ("But despite this general agreement on the need for improvement, there is little consensus on how health care literacy should be measured or assessed."). 
Whatever the DOL decides the appropriate literacy measures are, it should encourage plan administrators to focus on evaluating participant literacy ${ }^{259}$ rather than focusing on an objectively perfect final SPD - a goal that seems "almost impossible."260 This fits with ERISA's text, which requires a "calculated" method of SPD drafting, ${ }^{261}$ and aligns with the increased flexibility recommended in Part IV(A), while also ensuring that administrators continue to tailor communications to their participant population.

The DOL should also consider allowing administrators to use nontext communications to satisfy the SPD requirement. One speaker before the Advisory Council thought that "it might be impossible to make all of the details of health plans simple enough to be readily understood by most plan participants." ${ }^{262}$ But this might be solved by allowing non-paper communications - such as videos, presentations, and individual meetings - to satisfy SPD disclosure requirements. Evidence shows that video presentations are helpful in clinical settings when communicating information to individuals with low health literacy. ${ }^{263}$ And in one survey, $45 \%$ of respondents with employersponsored insurance believed that personalized benefit meetings would aid Americans in understanding benefits. ${ }^{264}$ Therefore, if a plan administrator finds that plan participants respond best to media that can be watched or heard instead of read, ERISA's goal of empowering plan participants through disclosure would best be met by allowing plan administrators to include that media in its SPD disclosures. ${ }^{265}$

Additionally, as part of enforcing readability, the DOL should consider which commonly included plan terms can be left out of the new SPD documents. Some plan terms - for instance, subrogation rights - are helpful only in special situations or are so legally complex

259. Advisory Council, supra note 136.

260. Advisory Council, supra note 25.

261. See supra notes $245-48$ and accompanying text.

262. Advisory Council, supra note 25.

263. Laurie Anne Ferguson, Implementing a Video Education Program to Improve Health Literacy, 8 J. FOR Nurse PrAcs. e17, e18 (2012). The National Assessment on health literacy focused on reading skills, KUTNER ET AL., supra note 3, at iv, but new communication avenues that have since developed from rapidly changing technology are another reason for a new national assessment on health literacy.

264. DirectPAth, supra note 10, at 2.

265. See supra notes 67-68 and accompanying text. The DOL may want to require that plan administrators also record any disclosures made through video or audio or put those disclosures in writing for ease of access. 
that they might not even be helpful when summarized in the SPD. ${ }^{266}$ But further consideration is needed to determine which plan provisions are helpful in what situations, and whether communications summarizing those provisions should be omitted from the new SPD documents or included in a different way - for instance, in a separate document. ${ }^{267}$

\section{Identifying the Average Plan Participant}

Another issue the DOL should consider when drafting new regulations is how best to interpret the word average in "average plan participant." 268 One shortcoming of a literal reading of "average plan participant" is that that reading would produce one benchmark measurement of literacy, even though a plan may cover participants with widely varying literacy skills. ${ }^{269}$ The word average could mean "the midpoint [value]" of a group or "the mean of a series," but it could also mean something as broad as "[t]he ordinary or typical level" or "the norm." "270 Therefore, the DOL may need to clarify how a plan administrator determines who the plan's average participant is, consistent with the goals of ERISA - most importantly, to prevent unfairness by informing participants of their benefits. ${ }^{271}$

Interpreting ERISA to require that SPDs are readable for the midpoint literacy value or mean among participants would result in an SPD that is understandable for only a portion of the plan's participants - and depending on how the math works out, that portion could be small and would, by definition, exclude participants with lower literacy levels. Additionally, ERISA does not include any quantitative measures for SPDs that could be plugged into a formula, so it would be strange for Congress to intend a mathematical reading of the word

266. Cf., e.g., WIEDENBECK, supra note 33, at 102 ("For example, the SPD for a group health plan might explain the benefits available in the event of disease or injury, but neglect to point out that the plan contains a subrogation clause calling for reimbursement of the plan if medical expenses are recovered from a tortfeasor. The missing information is unlikely to affect participants' behavior ...." (footnote omitted)); see supra notes 77-79 and accompanying text.

267. The Advisory Council recommended a "separate section" within the SPD for "technical and legally required information not directly related to the health benefits offered under the plan." Advisory Council, supra note 136. Creating a separate document with the legal information would implement the Council's recommendation in the new flexible SPD.

268. 29 U.S.C. $\S 1022$.

269. See supra text accompanying notes 102-03; supra note 239.

270. Average, Black's Law Dictionary (11th ed. 2019).

271. See sources cited supra note 72 . 
"average." 272 Therefore, a robotically literal reading of ERISA should be avoided because, in many cases, it may produce a result inconsistent with the statute's purpose. ${ }^{273}$ A reading more consistent with that purpose would be that Congress intended plan administrators to think of a representative plan participant, which accords with the broader definitions mentioned above. And if the DOL were to require literacy measures or other similar tests, then requiring plan administrators to reasonably connect the data from those tests to the determination of the average participant would effect ERISA's text and purpose.

The DOL could require that administrators produce separate documents for different participant groups. But that could put a potentially heavy burden on plans to produce multiple versions of the same materials. Instead, it would be simpler and more effective to use a plan's lower literacy scores as a benchmark because more literate employees should be able to understand simpler materials. ${ }^{274}$ Or a plan administrator could use a benchmark targeted at a large majority of the plan's participants - if the 2003 National Assessment is to be believed, that would likely be participants with "intermediate" literacy for most plans. ${ }^{275}$

Importantly, the DOL should draw a distinction between what is required and what is allowed. For instance, the DOL could require a plan administrator to use its lower literacy benchmarks if the administrator intends to produce only one set of materials, while also allowing the administrator to satisfy the SPD requirement by producing different documents tailored to various participant populations. ${ }^{276}$ But the DOL should ensure that participants can adequately rely on

272. 29 U.S.C. $\S 1022$. This Note is advocating for literacy measures based on the statutory language that plan administrators take "calculated" steps to ensure readable SPDs, not based on the word "average." Id.

273. See Griffin v. Oceanic Contractors, Inc., 458 U.S. 564, 575 (1982) ("[I]nterpretations of a statute which would produce absurd results are to be avoided if alternative interpretations consistent with the legislative purpose are available."); Kirtsaeng v. John Wiley \& Sons, Inc., 568 U.S. 519, 557 (2013) (Ginsburg, J., dissenting) ("In the interpretation of statutes, the function of the courts is easily stated. It is to construe the language so as to give effect to the intent of Congress." (quoting United States v. Am. Trucking Ass'ns, Inc., 310 U.S. 534, 542 (1940))).

274. The DOL should consider whether plans might be able to exclude outlier participants, especially if a plan covers hundreds of participants and only a few are at an extremely low literacy level. Even the Congress that passed ERISA understood that employers cannot practically meet the needs of all participants because some participants might have unique or unreasonable needs. See sources cited supra note 72 (noting that plan disclosures should be understandable by workers that are both "average and reasonable" (emphasis added)).

275. See supra text accompanying note 102.

276. See supra Part IV(A). 
materials that the plan produces. ${ }^{277}$ Certainly, the DOL is best equipped to determine how to meet ERISA's disclosure requirements in a manner that is consistent with the statute's purpose.

The changes recommended in this Part align not only with the Advisory Council's recommendation that the DOL better enforce ERISA's readability requirement ${ }^{278}$ but also with ERISA's text and purpose. ${ }^{279}$ For that reason, courts could make the recommended changes by interpreting ERISA's language accordingly. ${ }^{280}$ But given that courts would need to wait for appropriate litigation, ${ }^{281}$ that experts are likely needed to evaluate the effectiveness of any literacy tools, ${ }^{282}$ and that the DOL has broad authority to implement ERISA and to customize regulations, ${ }^{283}$ the DOL is better positioned than the judiciary to effect the recommendations in this Note.

\section{Interpreting SPDs in Court}

Assuming that the DOL makes the updates recommend above, the final question is how courts would interpret SPDs under regulations that focus on a plan administrator's drafting actions rather than an SPD's objective language. Under this Note's recommendations, the court would need to review whether administrators have drafted SPDs according to the DOL-created assessments discussed above. ${ }^{284}$ The court would then evaluate an administrator's actions rather than independently evaluate a plan's participants. In other words, rather than determine the reading level of the average plan participant, the court would evaluate the administrator's use of literacy tools when it drafted the SPD. If a plan administrator failed to adequately use literacy tools or act on them, then it failed its obligations under ERISA. ${ }^{285}$ As a result, the court could grant equitable relief against the administrator. This system creates a presumption: where a plan

277. See infra Part IV(C).

278. Advisory Council, supra note 25.

279. See supra notes $179-89$ and accompanying text.

280. See supra notes $177-78$ and accompanying text.

281. See Chafin v. Chafin, 568 U.S. 165, 172 (2013) ("Federal courts may not 'decide questions that cannot affect the rights of litigants in the case before them' or give 'opinion[s] advising what the law would be upon a hypothetical state of facts." ' (quoting Lewis v. Cont'l Bank Corp., 494 U.S. 472, $477(1990)))$.

282. See Comm. on Health Literacy, Inst. of Med., Health Literacy: A Prescription to End Confusion 43-51 (Lynn Nielsen-Bohlman et al. eds., 2004) (discussing the complexity of health literacy measures).

283. See supra notes $232-34$ and accompanying text.

284. See supra notes $248-58$ and accompanying text.

285. ERISA § 102(a), 29 U.S.C. § 1022(a); see supra notes 248-52 and accompanying text. 
administrator did not appropriately use literacy tools or tailor its SPD according to those tools, then the average plan participant could not have understood that SPD. ${ }^{286}$ But if the administrator met its obligations, then the court would conclude that the SPD is calculated to be understood by the average plan participant. ${ }^{287}$

But even if an SPD is understandable, the plan administrator still must ensure that the SPD is "sufficiently accurate and comprehensive," as required by ERISA. ${ }^{288}$ If a participant challenged an SPD's accuracy or completeness, then the court could interpret the SPD in light of the literacy tools that the plan administrator used when writing the SPD, taking into account any special terminology or formatting used for the participant population, ${ }^{289}$ but otherwise assuming that participants could understand the SPD - again, subject to the court first finding that the SPD is readable. ${ }^{290}$

\section{Helping Participants Rely on Employer Communications}

Lastly, allowing separate documents to be the SPD in place of one comprehensive document would address the reliance issues discussed in Part III(B). Based on the Supreme Court's decision in Amara, participants can obtain equitable relief for poorly written SPDs. ${ }^{291}$ Because the DOL can regulate the SPD's format, ${ }^{292}$ regulations that define separate benefit documents as the SPD would likely require

286. Courts could consider evidence that might rebut the presumption: for example, ex post evidence that the administrator, had it used literacy tools, would have produced the same SPD (or at least that the relevant provisions of the SPD would have been the same).

287. See supra notes 248-49 and accompanying text. This test matches the first prong of the test articulated in Hopkins v. Prudential Insurance Co. of America, 432 F. Supp. 2d 745, 758-59 (N.D. Ill. 2006) (citing Mers v. Marriott Int'l Grp. Accidental Death \& Dismemberment Plan, 144 F.3d 1014, 1022 (7th Cir. 1998)). See supra note 170 for that test.

288. ERISA $\S 102(a)$. For an example case where a court sided with participants because of an inaccurate SPD, see Fallo v. Piccadilly Cafeterias, Inc., 141 F.3d 580 (5th Cir. 1998). This case was pre-Amara, so the court finds that the SPD controls the plan terms. Id. at 584. After Amara's rule that SPDs cannot create plan terms, a court confronted with a similar situation to Fallo would need to write its decision in terms of equitable relief, even though it may reach a similar decision. POLK, supra note 199, at $\S 12: 38$.

289. See supra notes 249-51 and accompanying text.

290. This matches the second prong of the test articulated in Hopkins, 432 F. Supp. 2d at 759 (citing Mers, 144 F.3d at 1022-24). See supra note 170 for that test.

291. See supra notes 150-51, 165-67 and accompanying text.

292. 29 U.S.C. § 1029(c). 
courts to find that those separate documents are now the SPD, ${ }^{293}$ in contrast to some courts' past practices. ${ }^{294}$ This means that participants could potentially obtain equitable relief based on those documents.

Still, as recommended by the Advisory Council, the DOL would need to watch closely to see how courts analyze cases where participants sue because they relied on erroneous or incomplete language in the separate SPD documents. ${ }^{295}$ If courts apply the new regulations in a way that prevents participants from relying on the new SPD documents altogether, the DOL may need to "propose legislation to amend ERISA to restore the original purpose and status of SPDs that satisfy regulatory requirements." ${ }^{296}$

But allowing plan administrators to produce customized - even individualized-documents, and allowing plan participants to rely on those documents would motivate those administrators to create the benefit communications contemplated by ERISA, while hopefully loosening the gridlock that has caused SPDs to increasingly fail to meet ERISA's goal of empowerment through disclosure. ${ }^{297}$

293. In Hicks v. Fleming Cos., the Fifth Circuit looked at the SPD content requirements under both the United States Code and the DOL's regulations when determining whether a benefits booklet was the SPD, but it spoke of the SPD as a single document. 961 F.2d 537, 542 (5th Cir. 1992) (first citing 29 U.S.C. § 1022(b); and then citing 29 C.F.R. § 2520.102-3 (2020)). While current law does give the DOL broad authority to regulate SPDs, see supra notes 232-34 and accompanying text, courts may react negatively to DOL attempts to change SPDs to multiple disparate disclosures.

294. See supra notes 200-06 and accompanying text.

295. Advisory Council, supra note 25 (recommending that the DOL "[r]eview court decisions granting legal superiority to SPDs and, if necessary, propose legislation to amend ERISA to restore the original purpose and status of SPDs that satisfy regulatory requirements.").

296. Advisory Council, supra note 25.

297. See supra Part I(B). 


\section{Conclusion}

Employer-sponsored health benefits are subject to a multidocument disclosure scheme in ERISA, ${ }^{298}$ yet participants in employerprovided plans have only slightly better health literacy than other Americans. ${ }^{299}$ Health benefits are complex and continue to increase in complexity ${ }^{300}$ and plan administrators are struggling to meet ERISA's requirements while also effectively communicating benefits to plan participants. ${ }^{301}$ Therefore, SPDs, which should be useful benefit summaries, ${ }^{302}$ instead become complex legal documents that do not help plan participants. ${ }^{303}$

Courts, interpreting ERISA as requiring SPDs to be objectively understandable, have further eroded ERISA's protections for plan participants. ${ }^{304}$ ERISA's mandate - in text and purpose - is that plan participants receive communications that empower them to understand and utilize their benefits. ${ }^{305}$ Given that plan participants have a broad array of health literacy skills, from below basic to proficient literacy, plan administrators must tailor SPDs to their own participant populations to meet ERISA's goals.

The DOL can empower administrators by revising SPD regulations. First, plan administrators should be able to provide various disclosures - including video and audio media - in place of a single SPD document, as needed to best communicate plan benefits to their participants. Second, the DOL should ensure that plan administrators are taking calculated steps to make SPDs understandable, including requiring administrators to produce evidence of participant-literacy measurements, consultations with employee industry groups, or similar actions. ${ }^{306}$ Following the DOL's lead, courts will then hopefully apply ERISA's requirements accordingly and evaluate whether administrators are meeting their obligations rather than whether SPDs are objectively understandable.

In enacting these recommendations, the DOL can motivate healthplan administrators to tailor SPD documents to participants' needs, while providing administrators with the flexibility they need to create customized benefit communications. These regulatory changes fall

298. See supra text accompanying note 207.

299. See supra notes 102-03 and accompanying text.

300. Camillo, supra note 191, at 1; Advisory Council, supra note 25.

301. See supra notes $227-28$ and accompanying text.

302. See supra notes $73-74$ and accompanying text.

303. See supra notes 134-36 and accompanying text.

304. See supra Part III(A).

305. See supra notes 67-73 and accompanying text.

306. See supra notes $248-51$ and accompanying text. 
Case Western Reserve Law Review · Volume $72 \cdot$ Issue $1 \cdot 2021$ Making Employee Health Benefits Understandable

within the DOL's power ${ }^{307}$ and better effectuate ERISA's disclosure requirements because they would ensure that the new SPD documents are "written in a manner calculated to be understood by the average plan participant." 308

Christopher Switzer

307. See supra notes $232-34$ and accompanying text.

308. ERISA § 102(a), 29 U.S.C. § 1022(a).

$\dagger \quad$ B.A. 2013, Concordia University Ann Arbor; J.D. 2022, Case Western Reserve University School of Law; winner of the 2020-2021 Case Western Reserve Law Review Outstanding Student Note Award. Christopher spent several years working in the employee-benefits industry prior to attending law school. He thanks Professor Jonathan L. Entin for his guidance and insight, and thanks the following people for their thoughtful comments on drafts of the Note: Professor Russell C. Shaw, Jeffrey Zimon, Joyce Leinenger, Sarah Schneider, Andrew Rumschlag, and Athavan Balendran. He also thanks his friends and family who listened to countless rants about SPDs. 